\title{
Waste dump erosional landform stability - a critical issue for mountain mining
}

Running Head

\section{Landform stability in mountain mining}

Cristina Martín-Moreno ${ }^{1 *}$, José F. Martín Duque ${ }^{1,2}$, José M. Nicolau Ibarra ${ }^{3}$, Alfonso Muñoz ${ }^{1,2}$, and Ignacio Zapico ${ }^{1,2}$

${ }^{1}$ Geodynamics Department, Faculty of Geology, Complutense University of Madrid,

C/ José Antonio Novais 12, E-28040 Madrid, Spain

2 Geoscience Institute, IGEO (CSIC, UCM), C/ José Antonio Novais 2, E-28040 Madrid, Spain

3 Department of Agricultural and Environmental Sciences, Technical School, University of Zaragoza, Ctra. Cuarte s/n, E-22071, Huesca, Spain

*Correspondence to: Cristina Martín-Moreno. Geodynamics Department, Faculty of Geology, Complutense University of Madrid, C/ José Antonio Novais 12, E-28040 Madrid, Spain E-mail: crismartin@geo.ucm.es Tel.: +34 913944857

This article has been accepted for publication and undergone full peer review but has not been through the copyediting, typesetting, pagination and proofreading process which may lead to differences between this version and the Version of Record. Please cite this article as doi: $10.1002 /$ esp.4327 


\section{ABSTRACT}

Mining is the largest producer of solid wastes which, when released to land or into waterways, can cause harmful environmental impacts. This is mostly due to fluvial erosion, which is highly increased in mountain areas, due to abrupt slopes. We have analysed this situation at a mountain watershed (192 ha), ---------+ ${ }^{\star}(\mathrm{DoD})$ method to quantify erosion and sediment yield from three waste dumps (5 ha). Their topography and substrate properties were analysed to understand the erosion problem. The sediment trapped by the check dams was quantified by Electrical Resistivity Tomography. The rainfall characteristics triggering an episode that filled the check dams with sediment in the winter of 2009-2010, were studied to confirm whether it was a case of extreme precipitation conditions.

The waste dumps sediment yield $\left(353 \pm 95 \mathrm{Mg} \mathrm{ha}^{-1} \mathrm{yr}^{-1}\right)$ suggests severe landform instability. Analysis of topographic and substrate properties confirmed long, steep slopes combined with highly erodible materials. The check dams proved to be inefficient in controlling sediment loads, as they had only functioned for four years of 31 of existence, having trapped $13000 \pm 660 \mathrm{~m}^{3}$ of sediment, whereas we estimated that the waste dumps have yielded approximately three times more sediment for the same period. Rainfall analyses showed that neither intense nor extreme conditions (return period of 25-35 years) triggered the mobilization of $37 \pm 2 \mathrm{Mg} \mathrm{ha}^{-1}$ in a month. This study highlights the fact that mining operations in similar mountainous settings, with equivalent waste dump construction and reclamation practices, are currently unfeasible. We conclude that landform stability cannot be achieved at this site without landform changes.

KEY WORDS: landform stability, mining erosion, check dams, Electrical Resistivity Tomography (ERT), DEM of Difference (DoD). 


\section{Introduction}

The estimated annual global mine waste generation for 2011 was approximately 56 billion tonnes of waste rock and seven billion tonnes of tailings which is equivalent to about nine tonnes per human per year (Mudd and Boger, 2013). Mining is necessary for maintaining society's current life style and will continue to grow. However, mining can be detrimental to public health and safety, and may cause damage to the environment (on-site and off-site effects). This is due to mining-related removal of soils and vegetation and concomitant increased erosion, creation of large amounts of wastes and/or associated acid mine drainage (AMD) or increased suspended sediment loads in downstream waterways (Mossa and James, 2013). The generation of solid and liquid wastes and their release to land and into waterways are arguably the greatest impacts on the environment associated with mining (Franks, 2015). The export of runoff and sediment downstream (off-site effects) affects basic ecosystem services relating to water quality, fluvial wildlife conservation, recreation and flood control (Ehrenfeld, 2000), made worse by AMD.

In most situations, the root of the problem is the large amount of unconsolidated waste rock or tailing materials produced by mining operations that are accumulated near to the mining sites. They become new landscapes with a geomorphology often far from equilibrium and vulnerable to failures (Martín Duque et al., 2010). Collectively they are referred to as waste facilities or structures, and individually as heaps, piles or dumps — for waste rock-, and dams or ponds - for tailings - The use of heaps, piles and dumps can differ according to specific characteristics and ore recovering potential (see Orman et al., 2011), but they also refer to the same in different world regions. Here we will use 'waste dumps' (escombreras in Spain and botaderos in Ibero-America) to name the studied 
accumulations of waste rock, because it is the most common term in the geomorphic literature.

Landform instability of mining wastes rises sharply in mountainous physiographic settings, where long, steep natural slopes and narrow valleys impose difficult conditions for accumulation and stabilization. If other factors triggering instability are added to the constraints of mountains, the consequences can be dramatic in terms of effects on society and the environment (Table 1). Catastrophes such as the examples shown in Table 1 have led to an improvement in geotechnical solutions. However, even in a context of broad geotechnical stability, waste structures are usually far from geomorphic equilibrium, often leading to accelerated erosion, even when they are reclaimed (we use here reclaimed or reclamation, although rehabilitation and rehabilitated are equivalent terms).

This study deals with erosion at mining waste dumps in mountainous regions and sediment mobilization downstream. Waste dump erosion is common in mountain mining and leads to the formation of alluvium deposits in downstream valley bottoms, thus inducing further environmental impacts in a much larger area that the one affected by the mining operations. Wohl (2006) characterizes the detrimental effects of this process on mountain streams: there is a sharp increase in sediment mobility, a decrease in bed and bank stability, and channel geometry is altered; water quality is degraded by sediment and other contaminants; reduced instream and riparian habitat availability and quality; and, finally, the disturbance regime is altered.

The largest set of scientific evidence of geomorphic-based environmental effects in waterways located downstream from waste dumps comes from the socalled mountaintop removal mining (MRM), also mountaintop mining (MTM), of the Appalachian Coalfield Region of Eastern USA (Palmer et al., 2010). In this region, 
mining performed within a physiography characterized by significant differences in height (several hundred metres) and steep valleys has induced fundamental changes in the topography and morphology of watersheds, has greatly affected the water quality of downstream ecosystems (Lindberg et al., 2011) and led to heavier storm runoff and increased frequency and magnitude of downstream flooding (Phillips, 2004; Ferrari et al., 2009; Miller and Zégre, 2014).

As already referred, on-site and off-site effects occur at reclaimed waste dumps even with geotechnical stability measures, a condition applying to most of today's mine waste dumps. This is key, since this affects economic viability, legal liability, bond release and successful ecological recovery. The reason is that waste dump resistance to hydric erosion has not been solved satisfactorily. Artificially created topography may still be prone to erosion processes (Nicolau, 2003). At present, a growing body of literature is demonstrating that reclaimed waste dumps, even with geotechnical stability measures, are vulnerable to erosion (Haigh, 1979, 1980; Goodman and Haigh, 1981; Hahn et al., 1985; Riley, 1995; West and Wali, 1999; Evans et al., 2000; Evans and Willgoose, 2000; Kapolka and Dollhopf, 2001; So et al., 2002; Hancock et al., 2003; Hancock et al., 2008; Nyssen and Vermeerch, 2010; Merino-Martín et al., 2012; Beullens et al., 2014; Martín Duque et al., 2015). The most frequent mining reclamation approaches, based on terraced landforms and contour banks, tends towards hydric erosion, especially via rill generation (Morenode las Heras et al., 2011a) and the formation of gullies, owing to deficiencies in the functioning of berms and terraces during maximum rainfall events (Sawatsky et al., 2000). Inappropriate landform design has been claimed as a cause (Franks, 2015). This broad meaning and request for landform stability is evident in the mine reclamation regulations of different countries (Table 2), which means that the 
construction of stable post-mining landforms and erosion control are significant issues for many communities. Therefore, the purpose of this study is to describe and quantify erosional landform instability of waste dumps in a mountainous landscape, to improve mining operation and reclamation elsewhere.

This study was carried out within the Poveda de la Sierra - Peñalén Mining District (East-Central Spain), located at the edge of the Alto Tajo Natural Park. This area comprises five main mining operations (three abandoned and two active) for kaolin (Figure 1). All five sites benefit the same materials (kaolin-rich quartz-feldspar sandstones of the Arenas de Utrillas Formation) and have the same topographical setting at the edge of high altitude plateaus. Mining operations here are very similar to those of the MRM or MTM of the Appalachian Mountains in the eastern United States. MRM or MTM is a form of surface mining, mostly for coal, at the summit of a mountain. Explosives are used to remove the top of summit ridges to expose underlying coal seams. At the kaolin mines of the Alto Tajo, explosives are employed in a limited way, only to remove the limestone cap lying at the edges of broad plateaus above the kaolin sands. Once the kaolin sands have been exposed, their bed fronts in the quarries are removed by hydraulic excavators and bulldozers.

Within this mining district, we studied the Peñalén watershed, which includes the Santa Engracia inactive mine, with two abandoned mined sites. The site was chosen because high landform instability at this location has been blamed as the main source of sediment yielded to the Alto Tajo Natural Park, and considered the main environmental problem in this protected area (Martín-Moreno, 2013). Mine instability led to a series of gabion check dams being built within the watershed from the 1980s to trap the sediment eroded in the mined areas and, as also stated, "to 'stabilize' both streams and slopes". Therefore, the objectives of this paper are to: i) 
study the landform stability of poorly designed and reclaimed outslope dumps of loose sands with clay of a kaolin mountain mine by measuring their erosion; ii) quantify the sediment trapped by the downstream check dams, both for comparing erosion values at the dumps and to test their efficiency as a sediment control solution; iii) study the precipitation characteristics that triggered a recent episode of filling the check dams storage; and iv) develop better understanding of the mining system so that improved reclamation can occur.

\section{Study area and context}

Physical environment

The Peñalén watershed is located in the buffer zone of the Alto Tajo Natural Park (ATNP), in East-Central Spain (579535; 4502213, coordinate system UTM-30N, datum ETRS 1989). This protected area was established in 2000 by a regional law (DOCM, 2000) because of its outstanding geo- and biodiversity, especially in regard of the aquatic ecosystems. This area is also included in the Natura 2000 Network site Alto Tajo Special Protection Area (SPA, ES0000092) and in the Comarca de Molina-Alto Tajo Geopark.

The Peñalén watershed covers an area of 192 ha; 173 ha are connected to the fluvial network and 19 ha cover endorheic watersheds at mine sites. The Peñalén stream, $1.7 \mathrm{~km}$ long and at a mean gradient of $14 \%$, is a tributary of the Merdero stream, which in turn debouches into the Tagus (Tajo) River (Figure 2).

The Alto Tajo landscape is characterized by plateaus and mesas capped by Cretaceous carbonates (limestones and dolostones), in which the Tagus River has carved a canyon system over $100 \mathrm{~km}$ in length (Carcavilla et al., 2008). At the Peñalén watershed area, the plateaus have an altitude of approximately 1400 
m.a.s.l. and the mouth of the Merdero lies at 1025 m.a.s.I. Underlying the carbonates is a sandy sediment that holds the kaolin (Arenas de Utrillas Formation) excavated in several mines (Olmo and Álvaro, 1989). On the plateaus and flat tops of mesas, the soils are chromic luvisols, calcaric cambisols, mollic leptosols and rendzic leptosol. On the slopes, carbonate colluvia with calcaric cambisols are common (IUSS Working Group WRB, 2007). The vegetation is representative of Mediterraneancontinental environments, with communities dominated by Juniperus thurifera on the highest plateaus and pine (Pinus nigra subsp. salzmanii) and gall oak (Quercus faginea) covering the valley slopes (MARM, 1997-2006). There are also some areas of non-irrigated arable lands. The climate of this area is temperate Mediterranean with dry, mild summers (Csb, according to Köppen, 1918) but with a noticeable continental influence. The moisture regime is dry Mediterranean (Papadakis classification) (CNIG, 2004). Mean annual precipitation is $780 \mathrm{~mm}$ and mean annual temperature is $10^{\circ} \mathrm{C}$ (AEMET, 2016). According to the Thornthwaite method (Urbano Terrón, 1995) annual potential evapotranspiration is $679 \mathrm{~mm}$. The seasons in this area are characterized by long, cold winters, commonly with snowfalls, and short dry summers with high intensity rainstorms. The spring and fall are usually wet. The rainfall erosive factor, $\mathrm{R}$, is estimated to be about $800 \mathrm{MJ} \mathrm{mm} \mathrm{ha-1} \mathrm{h}^{-1} \mathrm{yr}^{-1}$ (ICONA, 1988). This value is not very high, as $R$ ranges from 350 to $5400 \mathrm{MJ} \mathrm{mm}$ $\mathrm{ha}^{-1} \mathrm{~h}^{-1} \mathrm{yr}^{-1}$ (ICONA, 1988) in Spain.

\section{Mining activity in the Peñalén watershed}

Since the $18^{\text {th }}$ century, if not before, iron ore has been mined (in galleries) and manufactured in the Peñalén watershed. This activity had ceased by the end of $19^{\text {th }}$ 
century. In 1924 iron mines were re-opened and remained active until 1936, when the Spanish Civil War commenced (García López, 2012).

In the late 1960s, mining activity started again within the Peñalén watershed. This time the mineral of interest was kaolin and the mining method used mechanized open pits. Figure 3 shows the increase in size of the Santa Engracia mine (blue circles) between 1977 and 2009.

The Cemetery mine site was opened in 1967; operation ceased after some years, but resumed again in 1980. In the same year, mining also began in the Path to Poveda site. At this location, three typical outslope waste dumps (as described by Haering et al., 2004) were built on top of the original slope, downstream from the mine (Figure 4). These dumps are also called sidehill dumps (Orman et al., 2011): a sidehill structure that lies along the side of a slope but does not cross a valley. Shortly after, work in the Cemetery mined site finished, but activity continued in the Path to Poveda site, until 1990.

In the 1990s, when mining activity ceased at the Path to Poveda site, the waste dumps, connected to the fluvial network, were poorly reclaimed -they were slightly regraded, by constructing a terraced topography and spreading colluvium on the benches. These terraces were severely eroded by gully erosion, triggering also mass movements. Revegetation works, consisting in planting various species of shrub failed, and natural plant colonization did not occur because of heavy erosion. Nowadays, only part of the original terraces are recognizable and they contain gullied incisions of up to $3 \mathrm{~m}$ (Figures $4,5 \mathrm{~A}$ and $5 \mathrm{~B}$ ).

Erosion has not only caused effects on-site, but off-site too. As stated above, the Santa Engracia mine sites have been identified as the most significant source of sediment in the Alto Tajo Natural Park (Figure 5D). 
Check dam construction at the Peñalén watershed

The severity of erosion, from the Santa Engracia waste dumps, prompted the construction of a series of gabion check dams (CD) in three periods (1981, 1984 and 2009-2010) as part of three separate Watershed Management Plans. Their purpose was to trap the sediments mobilized from the dumps to prevent transport to the Merdero stream and onwards to the Tagus River. In 1981, four 2-m high check dams were built in small watercourse tributaries of the Peñalén stream. In addition, a 4-m high check dam was built in the Peñalén stream, just before it joins the Merdero stream. In 1984, the storage areas of those check dams were filled by sediment and some were broken by debris flow, which formed debris cones within the valleys (Figure 5C). Following this, $4 \mathrm{~m}$ additional height was added to the existing 4-m check dam, to a total of $8 \mathrm{~m}$ in height (CD\#1 in Figure 2). The third Watershed Management Plan was carried out during the 2009-2010 winter; on this occasion the 8-m high check dam was partially cleaned and a new 4.5-m high check dam (CD\#1 in Figure 2) was built upstream from the previous one. In approximately one month (from 10 December 2009 to 18 January 2010), when CD\#1 was under construction and had reached 3-m high, and CD\#2 had been partially cleaned, their storage areas were completely filled by sediment. One month later, when CD\#1 had reached 4.5-m high, its storage area was completely filled again.

Recent ecohydrological changes in Peñalén watershed

Water quality and the health of aquatic ecosystems in the Alto Tajo region have become worse in the last few decades as a consequence of mining development. The trout (Salmo trutta) population declined in the 1990s, as well as economic activity related to sports fishing, both of which concerned the Natural Park 
authorities. Kaolin mines were considered the main drivers of such environmental and economic problems, since sediment (sand, silt and clay) originating from the mines presumably covered the spawning areas in the beds of the watercourses, which in turn limited trout reproduction (Rafael Ruiz, former Director of Alto Tajo Natural Park, pers. com.).

Mining in the area has not been the only cause of hydrological and ecological changes in these fluvial systems. Traditional land uses in the area, based on extensive ovine livestock, forestry and marginal agriculture, have also undergone a sharp reduction due to large numbers of people abandoning the countryside in the mid-20 ${ }^{\text {th }}$ century. As a consequence, a noticeable recovery of vegetation and wildlife is taking place, as shown in Figure 3. This is a general phenomenon occurring in Spain and other developed countries, with significant ecological effects, such as a decrease in water flowing along watercourses and a reduction in soil erosion (Rey Benayas et al., 2007). Fauna species are also recovering, including some fluvial species of trout predator, such as the otter (Lutra lutra) and the cormorant (Phalacrocorax carbo).

Although sediment production in the Peñalén watershed is a complex and a changing process with several drivers, the Santa Engracia mine is undoubtedly the major source of sediment in this watershed, causing the most adverse environmental effects to the Alto Tajo Natural Park (Martín-Moreno, 2013).

\section{Materials and methods}

Waste dump topography and substrata characterization

In order to study the erodibility of waste dump materials, nine composite samples of substrata were collected from the gullies and intergully areas of the three waste 
dumps (three samples for each waste dump). Each sample was formed by six subsamples distributed at random, which were homogeneously mixed to minimize spatial variability. General physico-chemical characteristics were determined: particle size distribution was measured by the pipette method (Gee and Bauder, 1986) and using the USDA textural classification; mineralogical composition was determined by X-ray diffraction (XRD) using a Bruker D8 ADVANCE diffractometer with Cu-Ka $(\lambda=1.54 \AA)$ radiation, and the relative amount of every phase was determined following the procedure by Chung $(1974 a, b)$. The content of sodium was measured by inductively-coupled plasma optical emission spectrometry (ICP-OES). Prior to analysis, samples were dissolved in deionized water, shaken during 24 hours and filtered; $\mathrm{pH}$ and electrical conductivity $(\mathrm{EC})$ were measured at $25^{\circ} \mathrm{C}$ by a CRISON pH-Meter basic 20+ and a CRISON EC-meter Micro CM-2200, respectively; finally, organic matter (OM) was estimated by the loss-on-ignition method (Netherlands Normalisation Institute, 1994). Additionally, bulk density was calculated by the core method (Blake, 1965). We took nine unaltered samples with an $8.2 \mathrm{~cm}$ high by 8.2 $\mathrm{cm}$ diameter core. Mean bulk density values were calculated for each waste dump and from the nine samples. Slope length and gradient were measured by topographical CAD analyses.

\section{Quantification of waste dump erosion}

To quantify the volume of eroded material at the three waste dumps (letters $A, B$ and C, Figure 6), we first built a Digital Elevation Model (DEM) representing the detailed topography of the eroded waste dumps (recent situation or 2009-DEM). To build this

DEM, we used the most recent high resolution public Airborne Light Detection and Ranging (LiDAR) data available (provided by the Spanish National Plan for Aerial 
Ortophotography, PNOA), with a minimum density of 0.5 points $\mathrm{m}^{-2}$ and a rootmean-square error in z (RMSEZ) of $20 \mathrm{~cm}$ (according to the technical specifications, PNOA, 2009). From this DEM, 1-m contours were generated and the area occupied by each waste dump delineated. Then, we erased the contours within the gullies, leaving only the parts representing the original terraces. Next, the contours of the original terraces were edited to reconstruct the original terraced topography. The oblique aerial photos taken in 1990, where terraces are visible (see Figure 4), were used as a reference. Field identification of the remains of the original terraces, preserved in the intergully areas, were also used. Following that, we built another DEM representing the terraced topography without gullies (1990-DEM). For this DEM we also assumed a RMSEZ of $20 \mathrm{~cm}$ equal to the raw point cloud.

Finally, both DEMs, the original reconstructed terraced, 1990-DEM, and the one representing a recent situation with gullies, 2009-DEM (Figure 7), were used to produce a DEM of Difference (DoD) by using the Geomorphic Change Detection (GCD) software (GCD, 2014). DoD measures the net change corresponding to erosion and deposition budgets (Wheaton et al. 2010). In this case, the volume of waste eroded since the terracing landform construction, from 1990 to 2009. DoD uncertainty was estimated specifying a minimum level of detection threshold (minLoD) which let us distinguish real geomorphic changes (above minLoD) from noise (below minLOD). Additionally, GDC software uses this minLoD to calculate the error of the volume of waste eroded, which is estimated, in turn, from those areas where real geomorphic changes can be detected. The minLoD was calculated assuming that individual errors of each DEM - the current (2009-DEM) and the original reconstructed terraced (1990-DEM) - are propagated, as expressed in the following equation (adapted from Wheaton et al. 2010): 


$$
\delta u_{D O D}=\sqrt{\left(\delta z_{2009-D E M}\right)^{2}+\left(\delta z_{1990-D E M}\right)^{2}}
$$

where $\delta u_{D O D}$ is the propagated error in the DoD, and $\delta z_{2009-D E M}$ and $\delta z_{1990-D E M}$ are the individual errors for 2009-DEM and 1990-DEM respectively. The error is assumed to be $20 \mathrm{~cm}$ in both cases. Hence, the propagated error used as minimum level of detection threshold (minLoD) was $\pm 28 \mathrm{~cm}$.

The mass of eroded waste $(\mathrm{Mg})$ was calculated by multiplying the volume $\left(\mathrm{m}^{3}\right)$ by the waste bulk density. We also measured the projected area of each waste dump by using the 2009 orthophoto (PNOA, 2009), and ArcGIS 10.2 software. The mean annual total erosion (equivalent here to sediment yield, since no sedimentation occurs within the gullies) for each waste dump, in terms of $\mathrm{Mg} \mathrm{ha}^{-1} \mathrm{yr}^{-1}$, was calculated by dividing the mass of waste $(\mathrm{Mg})$ by the area of each dump (ha) and the 19-year time span in which the recorded erosion took place (1990-2009).

\section{Quantification of sediment trapped by the check dams}

To calculate the volume of sediment trapped by check dams \#1 and \#2, we used Electrical Resistivity Tomography (ERT). ERT is a common geophysical technique used to investigate subsurface geometry and to characterize ground materials in mineral exploration, archaeology and environmental studies, among others (Dentith and Mudge, 2014).

The geophysical parameter used to characterize the ground is resistivity $(\Omega \cdot m)$, which expresses the resistance that the ground opposes to DC electrical currents. Ground resistivity ( $\rho_{\mathrm{ap}}$, in $\Omega \cdot \mathrm{m}$ ) is related to various geological parameters, such as the mineral content, porosity and degree of water saturation in the substrata (Dentith and Mudge, 2014). Multiple electrodes are driven into the ground and 
connected by a multi-core cable with a Resistivity-meter and power supply. DC current is supplied to two electrodes (current electrodes) and voltage differences are measured between another two electrodes (voltage electrodes). Apparent resistivity $\left(\rho_{a p}\right)$ value is calculated from the following equation (Reynolds, 2011):

$$
\rho_{\mathrm{ap}}=\mathrm{K} \frac{\Delta \mathrm{V}}{\mathrm{I}}
$$

Where:

$\Delta V=$ potential difference between a pair of electrodes

$I=$ current intensity introduced into the ground, and

$K=$ geometric factor which depends on the distances between voltage and current electrodes.

Usually an array with a large number of equidistant electrodes is used and a resistivity value is calculated by each four-electrode location. The injection and voltage electrodes are displaced automatically along the line to obtain resistivity values for a depth level. When all the resistivity values have been calculated with the same electrode separation, the distance between current and voltage electrodes is increased to calculate resistivity at a deeper level. This process is repeated until the vertical section is completed. The depth of investigation is limited by the electrode array length, as well by the current used (typically the total depth of penetration is approximately $20 \%$ of the electrode array length).

Two-dimensional data comprise pseudo-depth maps which may be displayed as images or contours, but the true form of the subsurface electrical structure usually is not easily recognisable. As a consequence, inverse modelling is an integral part of resistivity interpretation (Reynolds, 2011). The inversion is based on finite-element 
modelling, with a routine that calculates synthetic apparent resistivity data as a function of pseudo-depth, for a true resistivity-depth model. Elevation data should also be used to correct for irregular topography at the start of the inversion process. The process is repeated automatically for either a set number of iterations or until the percentage root-mean-square error (RMSE) falls below an acceptable value.

The interpretation of data measured is in two steps: firstly the physical interpretation, obtaining a physical model; and secondly the geological interpretation of this model (Dahlin, 2001; Muñoz Martín et al., 2007).

Five ERT profiles were made in July 2012; two at the storage area of check dam \#1 and the remaining three at the storage area of check dam \#2 (Table 3 and Figure 8). We used the RESECS DMT system with 48 electrodes separated at $2.5 \mathrm{~m}$ and a Wenner-Schlumberger array. We performed two injection cycles with reversed polarity and $120 \mathrm{~V}$. Over 250 values of voltage and intensity current were captured for each injection, and the error and variation in the standard deviation for each mean measurement were calculated. To obtain the real resistivity distribution at depth and its subsequent geological interpretation, we used the RES2DINV code inversion method (Loke and Barker, 1996) with four-node trapezoidal finite elements. Finally, we interpreted the geology over the $2 \mathrm{D}$ resistivity models and identified contact between substrata and sediment trapped by the check dams.

To calculate the volume of sediment trapped by the check dams, we assigned XYZ coordinates to each ERT profile by using a GPS on 1:1000 cartography and a tape measure. We also assigned the coordinates to each electrode and to each thickness value of sediment infill. Then, we added the mapped infill limit (each check dam storage area) as a boundary condition (thickness $=0 \mathrm{~m}$ ) and a regular net of 1 
$\mathrm{m} \times 1 \mathrm{~m}$ was interpolated by the minimum curvature method in order to build the infill isopach map of each check dam storage area.

To quantify the mass of sediment, we multiplied the calculated volume $\left(\mathrm{m}^{3}\right)$ by the sediment bulk density $\left(\mathrm{g} \mathrm{cm}^{-3}\right)$, obtained by the core method (Blake, 1965). We took five samples at the surface of the storage areas behind check dam \#1 and \#2.

Analysis of rainfall and its relation to the check dam filling process

Between 10 December 2009 and 18 January 2010, a period of continued precipitation caused by winter cold fronts occurred in this area. This front, which included rain and snow, triggered erosion and mobilized sediment that filled the check dam storage. The rainfall characteristics of this period and the volume of sediment trapped by the check dams for the same period were correlated. Rainfall was registered by a tipping-bucket automatic rain gauge $(0.2 \mathrm{~mm} /$ pulse) (Davis Instruments, 2005) with a HOBO Event data logger. From these data, we calculated the total rainfall volume $(\mathrm{mm})$ for this period, its return period in years $(T)$, the maximum rainfall volume in $24 \mathrm{~h}(\mathrm{~mm})$, the maximum rainfall volume in 60 minutes $\left(\mathrm{I}_{60}, \mathrm{~mm} \mathrm{~h}^{-1}\right)$ and the maximum rainfall volume in $30 \mathrm{~min}\left(\mathrm{I}_{30}, \mathrm{~mm} \mathrm{~h}^{-1}\right)$. To calculate the return period, the historical data series from Peñalén, Zaorejas and Beteta weather stations were analysed with the CHAC software (CEDEX, 2004). The General Extreme Values (GEV) frequency distribution was used with Maximum Likelihood Estimation (MLE) method. The return period was estimated graphically using the GEV curves calculated for each station.

The volume of sediment trapped by the check dams for this same period was extrapolated from the ERT results. To calculate the volume we took into account that on 10 December 2009, CD\#1 was under construction (unfinished), standing only $3 \mathrm{~m}$ 
high. By that date, CD\#2 had been partially cleaned; more specifically, a 1-m depth of the sediment trapped behind the dam had been removed from the storage area (Figure 9). We used Surfer 11 software to calculate the volumes. Once again, the volume $\left(\mathrm{m}^{3}\right)$ obtained was multiplied by the mean bulk density to obtain the mass of sediment $(\mathrm{Mg})$. Knowing the Peñalén watershed area connected to the fluvial network (173 ha), we computed the sediment yield for 10 December 2009 - 18 January 2010, in terms of $\mathrm{Mg} \mathrm{ha}^{-1}$ (approximately in one month).

\section{Results}

\section{Waste dump topography and substrata characterization}

Table 4 shows the topographic and substrata physico-chemical properties of the three studied waste dumps, which have long, steep slopes (from $50 \mathrm{~m}$ to $127 \mathrm{~m}$ of length and from $55 \%$ to $60 \%$ gradient). Texture is sandy loam with high percentage of sands (> $72 \%$ ) and low proportion of silt (10.6 \% mean) and clays (13.6 \% mean). Mineralogy basically comprises quartz ( $70 \%)$, kaolinite $(9.3-20.3 \%)$, calcite $(1.7$ $-7.3 \%)$, dolomite $(1-2.7 \%)$, mica/illite $(4-6.3 \%)$, k-rich feldspar $(1.3-3.7 \%)$, ankerite, plagioclase and hematite. The sodium content, electrical conductivity and organic matter are very low. The $\mathrm{pH}$ values vary from 8.63 to 8.91 . Finally, the mean bulk density is $1.54 \pm 0.04 \mathrm{~g} \mathrm{~cm}^{-3}$.

\section{Quantification of waste dump erosion}

The volume eroded at waste dump (A) (see Figure 6) from 1990 to 2009, was 10886 $\pm 2827 \mathrm{~m}^{3}$, equivalent to $16764 \pm 4354 \mathrm{Mg}$. For an area of 2.64 ha and for 19 years, mean annual erosion was $334 \pm 87 \mathrm{Mg} \mathrm{ha}^{-1} \mathrm{yr}^{-1}$. For waste dump (B), the eroded volume was $7827 \pm 1649 \mathrm{~m}^{3}$, equivalent to $12054 \pm 2539 \mathrm{Mg}$. Its mean annual 
erosion (for $1.34 \mathrm{ha}$ ) was $473 \pm 100 \mathrm{Mg} \mathrm{ha}^{-1} \mathrm{yr}^{-1}$. Finally, $3455 \pm 1513 \mathrm{~m}^{3}$ (5321 \pm $2330 \mathrm{Mg}$ ) were eroded at waste dump (C), so the mean annual erosion (for $1.11 \mathrm{ha}$ ) was $252 \pm 110 \mathrm{Mg} \mathrm{ha}^{-1} \mathrm{yr}^{-1}$. In total, $22168 \pm 5989 \mathrm{~m}^{3}(34139 \pm 9223 \mathrm{Mg})$ were eroded at the Santa Engracia waste dumps. This yields a mean annual erosion over the 19 years of $353 \pm 95 \mathrm{Mg} \mathrm{ha}^{-1} \mathrm{yr}^{-1}$ (Table 5).

\section{Quantification of sediment trapped by the check dams}

According to the ERT results, the thickness of the sediment trapped by CD\#1 reached a maximum of $5 \mathrm{~m}$ and had higher resistivity than the substrate (Figure 10). This is because the substrate consisted of well-sorted sands and fairly compact (weakly cemented) sandstones (Arenas de Utrillas Formation), while the trapped sediments were more porous, unconsolidated sand, gravel and carbonate rock fragments, which translates into higher resistivity (>160 $\Omega \cdot \mathrm{m}$, Figure 10$)$. In the case of CD\#2, the maximum thickness of the trapped sediment was about $9 \mathrm{~m}$ (Figure 10). The gradient of the contact surface between the trapped sediment and the substrate is constant upstream from the check dam, but varies sharply close to the check dam. CD\#2 was built on carbonate materials, so in this case, the sediment presents resistivity values lower than the substrate $(<100 \Omega \cdot m$, Figure 10$)$. In both cases, the sediment closest to the check dams has low resistivity $(<40 \Omega \cdot m)$, and can be as little as $10 \Omega \cdot m$, typical of 'pure' clays.

The positioning error of ERT profiles is estimated at $1 \mathrm{~m}$ for $\mathrm{XY}$ and $0.5 \mathrm{~m}$ for

$Z$; therefore the error in sediment thickness estimations is about $0.5 \mathrm{~m}$. The error and variation in the standard deviation for each ETR profile were $<10 \%$ and the final $2-D$ resistivity models had RMS errors below $5 \%$, hence the calculated volume uncertainty assumed is about $5 \%$. Consequently, the total volume of sediment 
trapped by CD\#1 was approximately $2700 \pm 140 \mathrm{~m}^{3}$, and $10300 \pm 520 \mathrm{~m}^{3}$ by CD\#2. The mean bulk density of the trapped sediment calculated was $1.57 \pm 0.03 \mathrm{~g} \mathrm{~cm}^{-3}$, therefore the equivalent mass of sediment was $4200 \pm 210 \mathrm{Mg}$ for CD\#1 and 16200 $\pm 810 \mathrm{Mg}$ for CD\#2 (see Table 6).

Sediment trapped by CD\#1 came from material eroded between 10 December 2009 and 18 January 2010 (when the check dam was only 3-m high) and from sediment trapped after 18 January 2010, once the check dam was finished and stood $4.5 \mathrm{~m}$ high. According to the workers who carried out the last Watershed Management Plan, the storage area upstream of CD\#1 was totally filled within one month after 18 January 2010; therefore, it can be said that this storage area was completely filled in two months.

Sediment trapped by CD\#2 has a more complex temporal interpretation, because it had been trapped from 1981, when CD\#2 was built, to 2012, when the ETR was performed (31 years). In addition, it must be borne in mind that during the last Watershed Management Plan, this storage area was partially cleaned but filled again in approximately one month (10 December 2009 - 18 January 2010).

\section{Analysis of rainfall and its relation to check dam filling}

The total rainfall volume for the period 10 December 2009 - 18 January 2010 was $351 \mathrm{~mm}$. The maximum rainfall volume in 24 hours registered during this period was $49 \mathrm{~mm}$ and the maximum rainfall volume in 60 minutes and in 30 min were $9.4 \mathrm{~mm}$ $\mathrm{h}^{-1}$ and $12 \mathrm{~mm} \mathrm{~h}^{-1}$ respectively. The return period, graphically estimated by using the historical data from Beteta, Zaorejas and Peñalén weather stations, was between 25 and 35 years (Figure 11). 
For the studied period, CD\#1 trapped $1100 \pm 60 \mathrm{~m}^{3}(1700 \pm 90 \mathrm{Mg})$ of sediment. The recently cleaned storage area behind CD\#2 was filled by a volume of $3000 \pm 150 \mathrm{~m}^{3}$, equivalent to $4700 \pm 240 \mathrm{Mg}$. To sum up, from 10 December 2009 to 18 January 2010 both check dams trapped a total sediment volume of about $4100 \pm$ $210 \mathrm{~m}^{3}$, or approximately $6400 \pm 330 \mathrm{Mg}$ (Table 6). Taking into account that the area of Peñalén watershed connected to the fluvial network is 173 ha, sediment yield was about $37 \pm 2 \mathrm{Mg} \mathrm{ha}^{-1}$ in one month.

\section{Discussion}

\section{Erosion rates and check dam sediment control}

The mean annual erosion (equals to sediment yield here), $353 \pm 95 \mathrm{Mg} \mathrm{ha}^{-1} \mathrm{yr}^{-1}$, is in the same order of magnitude as values measured in other severely eroded mine sites, most of them on sandy mine wastes without reclamation (Table 7). However, sediment supply from the Santa Engracia waste dumps to the fluvial network is likely to have been higher than those calculated, as according to the miners and to the Peñalén neighbours (pers. com.), the waste dumps underwent intense erosion processes, including mass movements, during their construction (when check dams did not exist).

These values and facts imply severe erosion conditions and therefore, high landform instability. The reasons for such intense erosion in this location are not related to run-on entrance and are numerous:

i) the waste dumps were built with relatively easily erodible materials (loose sands, > $72 \%$, with clay and silt, sandy loam texture, and a low percentage of organic matter); in fact, as directly observed in the field, surface erosion on these waste materials occurs virtually after every 
rainstorm. The low values of EC and content in sodium, and the lack of evaporite minerals (salts), indicated that Santa Engracia waste dumps are not susceptible to tunnel erosion and dispersive behaviour processes usually described for sodic and saline soils (So and Aylmore, 1993)—, so that we interpret that the main factor influencing the waste materials erodibility is the particle size distribution (Hancock et al., 2008) —sandy loam textures are prone to rill and gully erosion, and fine sand content, high here, increase significantly erodibility. In addition, the low organic matter content could favour erosion due to difficulties for aggregate formation.

ii) The construction technique was a direct waste dumping process on long, steep natural slopes.

iii) Waste dumps had single linear long, steep slopes (maximum slope length up to $127 \mathrm{~m}$ and mean gradient up to $58 \%$ ), which is a critical issue in the development of erosion processes (combined with high erodible materials).

iv) Ineffective reclamation measures to control erosion and sedimentation were applied.

The results demonstrate a very low efficiency of the check dams. The volume of material eroded at the waste dumps over 19 years (1990-2009) was $22168 \pm 5989$ $\mathrm{m}^{3}$ and the total volume of sediment trapped by the check dams in 31 years (19812012) was $13000 \pm 660 \mathrm{~m}^{3}$. Therefore, at least $9168 \mathrm{~m}^{3}$ of sediments could have reached the Merdero stream and, in turn, the Tagus River. The eroded volume for 1990-2009 (19 years) can be interpolated from the rainfall record for the 1981-2012 period ( 31 years). This shows that the material eroded at the waste dumps for the 
latter period would be $36169 \mathrm{~m}^{3}$, and the volume supplied to the Tagus $23169 \mathrm{~m}^{3}$, which is approximately $2-3$ times more, respectively, than the sediment trapped by the dams. Additionally, the check dam life span was expected to be several decades; however, they were filled in a much shorter time.

According to Rafael Serrada (manager of the 1980s Watershed Management Plans, pers. com) the check dams built in 1981 were totally filled in approximately three years, and CD\#2, raised during the second Watershed Management Plan in 1984, was filled in about one year. As stated by the workers who built the check dams in 2009-2010, these were filled in two months. This means that the check dams have had a lifespan of about four years. In short, the use of check dams as a structural solution for controlling the impact of mining was unsuitable. The reasons are that they: (i) were inefficient as a sediment control measure; (ii) had, in themselves, a high environmental impact, given their artificiality and ecological effects in the fluvial systems of a protected area; (iii) posed erosion problems for their surroundings arising from their construction and the building of access roads, as reported elsewhere (Brandt, 2000); and (iv) were very expensive.

A clear conclusion arises here. It is much more efficient (and ecological) to concentrate on stabilizing the sediment source area than trying to control and store the sediment yielded by check dams. Should the Peñalén watershed have no check dams and stably reclaimed mined areas, it would not have: a segmented longitudinal fluvial profile; an altered sediment dynamics; free longitudinal movement of nutrients and aquatic organisms (Wohl, 2006), all of which are important functions within a protected area.

The last episode of check-dam filling (between 10 December 2009 and 18 January 2010) was not the result of any extreme event, but just normal conditions. 
The total volume of rainfall registered had a return period as $25-35$ years and recorded intensities were not very high. The maximum intensity in 60 minutes for this period was $9.4 \mathrm{~mm} \mathrm{~h}^{-1}$, classified as moderate according to AEMET (2015). We interpret this as erosion and sediment yield for this period not being activated by high intensity rainfall, but due to the effect of continuous precipitation, which saturated the material. Saturation not only greatly favours runoff, it also causes loss of cohesion in materials, which can trigger mass movements that mobilize materials from the slopes to the bottom of the valley (Garland and Olivier, 1993).

All the measured evidence indicate that waste dump erosion at this location has been, and remains, very high. Thus, once the check dams are already totally filled, the current sediment emission from the mined areas to the fluvial network of the Alto Tajo Natural Park remains, continuing the loss of ecosystem services, as a consequence of externalized costs by unsustainable mining practises.

\section{Implications for contour and/or mountain mining viability}

Steep and/or mountainous terrain is constrained by "lack of space" to dispose waste. Valleys fills have been, and are, a common solution for disposing or accommodating waste in mountainous terrains, and always have a high environmental impact.

This study highlights the fact that proper stabilization and reclamation of waste dumps should be a critical issue for mining in mountainous terrain. In these settings, effective control, from the short to the long term, of on- and off-site effects and minimizing the damaging environmental impacts caused by these, is a must. This is more critical when, in addition, mountain mining takes place in the vicinity of protected areas. 
Mountain mining implies the presence of long, steep natural slopes, where accumulation of unconsolidated mine waste often have intrinsically high vulnerability to erosion and to mass movements. If weather conditions are also prone to causing high erosion, common in mountainous areas, the waste dump landform stability becomes a critical issue.

We demonstrate that waste (hillside) dumps built by direct dumping on nearby slopes, which has been a common practise, gives rise to high instability. Reshaping, by building terraces and by spreading colluvium on benches, was not sufficient to stabilize the facilities, and was just a 'makeup' measure. The difficulties in reaching long-term stability, but also for finding space to dispose the waste under these physiographic conditions, have been reported for the Appalachian Mountains. The enactment of the previously mentioned SMCRA in the United States required all mining spoil to be stabilized and returned to the 'approximate original contour (AOC)' (Brenner, 1985). For the mountain mining of the Appalachia, this meant that the extensive highwall cuts had to be covered and returned to contour, filled with spoils. But several authors (Brenner, 1985; Bell et al., 1989; Zipper et al., 1989) demonstrated that the use of this $A O C$ requirement in these steeply sloping topographies, led to common slope instability, excessive mining costs, increased erosion and loss of value in post-mining land use. The main reason for these failures was that this type of $A O C$ reclamation cannot replicate the original geological structure and soil properties, and that steep topographies on unconsolidated mining wastes lead to general instability.

Building stable waste dumps is therefore critical, but in order to find solutions, understanding and quantifying the stability of mined landforms (reclaimed or not) in 
real scenarios of steep slopes is essential. Especially if they have had a few years (preferably decades) of geomorphic evolution, as in the case we report here.

In search of durable landform stability of mine waste dumps

In the last two decades, a growing number of researchers and practitioners have identified landform instability as a limiting factor for successful mining reclamation, soil development and revegetation (references at Introduction section). The development of valuable new tools to improve landform performance has grown at the same time. This is the case of erosion models, such as a specific version of USLE for evaluating erosion in mined sites, RUSLE 1.06 (Toy and Foster, 1998); the SOILOSS model, an adaptation of USLE developed in Australia (Rosewell and Edwards, 1988); the WEPP (Water Erosion Prediction Project, Nearing et al., 1989), applied in mined areas by Elliot et al. (1993); the adaptation of the Thornes model by Moreno-de las Heras et al. (2011b); also the MUSLE approach (Modified Universal Soil Loss Equation, Williams, 1975) fitted to mined sites as well (Fifield, 2001). Landscape Evolution Models, LEM, mostly SIBERIA (Willgoose et al., 1989) have been widely used in this context (Hancock et al., 2008, 2016), but also CAESAR (Coulthard et al., 2002). There is also a fluvial geomorphic landform design method (GeoFluv) with its CAD-based software (Carlson Natural Regrade) that has been largely applied in the United States, whose potential use as a solution for mining reclamation in mountainous areas is being evaluated (DePriest et al., 2015). Any of these methods and models have potential use here.

We suggest a series of landform guidelines for stabilizing and reclaiming the kaolin mountain mined sites of Santa Engracia: (a) lowering the gradient of the linear slopes of the three main waste dumps, by removing materials at their upper reaches; 
(b) adopting a natural catchment approach for reclamation, regrading mature smooth valleys in these gentle slopes until slope and channel stability is reached (c) the excess of materials cut at the upper reaches of waste dumps and in the valleys would partially fill the pit between the highwall and external waste dumps, building also mature stable natural catchments; (d) finally, the remaining outcropping upper part of the highwall could be reshaped mimicking analogous natural landforms for the physiographic setting, such as stable cliffs. Once the foundations for landform stability have been laid, additional and indispensable soil replacement and revegetation measures should complete a holistic ecological approach. Ecological recovery is not likely without landform stability.

\section{About methodology}

The methodology used to calculate erosion at the waste dumps has certain limitations. Firstly, although LiDAR data is of high quality and meets international standards (ASPRS, 2014), the point cloud density used to obtain the 2009-DEM (recent situation) is not sufficient to represent the complex topography of the gully system developed on the waste dumps. In addition, field evidence indicates that some of the intergully areas are not in their original position, as they have been eroded and are lower than the original terraced topography. Secondly, the degree of uncertainty of the reconstructed topography (1990-DEM) of the interpreted original waste dumps is presumably high. Thirdly, we assumed that individual DEMs' errors were the RMSEZ $-20 \mathrm{~cm}$ - but solely because it is the only error available and reported in the technical specifications of the raw point cloud (PNOA, 2009). Although this reliability was not checked in the field (as recommended, Wheaton et al. 2010), it is like other errors reported for LiDAR data used with GCD software 
which can range between 11 and $26 \mathrm{~cm}$ (Schaffrath et al., 2015). Finally, the volume of eroded sediment calculated by using the DoD methodology has a highly uncertainty, ranging from $\pm 21 \%$ to $\pm 44 \%$ (see Table 5).

Despite these limitations and uncertainties, we believe that the methodology used is an acceptable approach to estimate waste dump erosion.

The ETR profiling used to calculate volume and mass of sediment trapped by the check dams also presents errors and uncertainties. Estimated errors relating to the position or resolution of ERT are below $0.5 \mathrm{~m}$. Nevertheless, the main source of uncertainty is the lack of $3 D$ information to assess the full geometry of the dam infilling. This absence has been solved by obtaining longitudinal, transverse and oblique tomographic sections along the dams. The incorporation of the mapped limit of the check dam storage area as a boundary condition allowed us to calculate more realistic volumes. This methodology guarantees that surface contact between substrata and sediment trapped by the check dams is identified correctly, thus obtaining the geometry of the storage areas with a good degree of precision (Ahmad et al., 2009).

Regarding rainfall analysis and its relation to filling the check dams, the main limitation is that we only registered rainfall, but not snow. We already know that, during the studied period, snow precipitation also occurred, in some occasions with rain on snow, causing rapid melting and heavy sediment mobilization. The geomorphic relevance of such a process has been described, for instance, in the central Pyrenees (López-Moreno and García-Ruiz, 2004).

Despite these limitations, we consider that the methodology used allowed reliable data to be obtained to make a quantified diagnosis of the described problem. 


\section{Conclusions}

Historically, the Peñalén watershed in East-Central Spain has been subject to natural high erosion processes and sediment fluxes into the Tagus River, including areas (such as gullies) that have been the source of a significant amount of sediment yield. This high geomorphic activity is conditioned by the extremely strong energy of the watershed relief, the existence of erodible geological outcrops (kaolin sands and clay) and weather erosivity factors, as shown by active gullying and shallow slides. This 'natural' erosion has been part of the dynamics of the watershed over the last few centuries, with variations associated with land use changes (affecting vegetation cover). Despite this, the fluvial ecosystems have adapted to these conditions, because of the slow rate at which land use changed. However, this situation was severely disrupted by intensive mechanized opencast mountain mining activities in the watershed, starting in 1967.

Mining operated without considering the high vulnerability of the physiographic setting for landform stability and took no account of stable landform designs, which led to very high erosion-sediment yield from the Santa Engracia waste dumps (353 \pm $95 \mathrm{Mg} \mathrm{ha}^{-1} \mathrm{yr}^{-1}$, mean).

Once this landform instability became evident, in 1981, check dams were adopted as a solution, to avoid unacceptable sediment yields to pristine fluvial ecosystems. Check dams, in addition to having an intrinsically high environmental impact, were very inefficient at storing the sediment eroded within the watershed.

This study, one of the few that reports erosion rates in mountain mining, highlights the fact that this type of mining is inviable, here and elsewhere, with such poor waste dump landform stability consideration and reclamation practices. Therefore, new ways of mining operation and reclamation, as an integrated process, 
need to be developed in such contexts. After having quantified the erosion and sediment yield from three waste dumps, and having analysed their topography and substrate properties, we also conclude that any action aimed at 'restoring' here balanced runoff and sediment fluxes should be based on sound geomorphic solutions, rebuilding functional natural catchments, with stable slopes and drainage networks, implying therefore landform changes that must be completed by additional and indispensable soil development and revegetation measurements. We believe that the conclusions of this work can be used for better environmental performance in mountain mining, avoiding undesirable situations like the one described.

\section{Acknowledgements}

This work was funded by a research contract between the Spanish mining company

CAOBAR S.A. and the Department of Geodynamics of the Complutense University of Madrid (research contract numbers, 196/2013, 222/2011, 261/2009). The data analyses and manuscript production were developed within the Research Project CGL2010-21754-C02-01 of the Spanish Ministry of Science and Technology and by the Ecological Restoration network REMEDINAL-3 (S2013/MAE2719). The authors want to thank the Consejería de Economía, Empresas y Empleo, Junta de Comunidades de Castilla-La Mancha for the images ceded and Nestor Hernández for his help in field work. Roberto Oyarzun provided key input all thorough the manuscript. We finally thank two anonymous reviewers and Greg Hancock (University of Newcastle, Australia) for thorough and instructive comments.

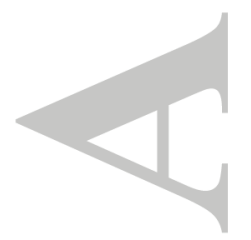




\section{References}

AEMET. 2016. Agencia Estatal de Meteorología. (Spanish Meteorological Agency). http://www.aemet.es/es/portada [accessed 2 January 2017].

AEMET. 2015. Manual de uso de términos meteorológicos. Edición 2015. Ministerio de Agricultura, Alimentación y Medio Ambiente. Available at: http://www.aemet.es/documentos/es/eltiempo/prediccion/comun/Manual de uso de terminos met 2015.pdf [accessed 2 January 2017].

Ahmad J, Schmitt DR, Rokos CD, Pawlowicz JG. 2009. High-resolution seismic and resistivity profiling of a buried Quaternary subglacial valley: Northern Alberta, Canada Geological Society of America Bulletin 121: 1570-1583 DOI: 10.1130/B26305.1

Alberta Government. 2005. Code of practice for exploration operations (made under the Environmental Protection and Enhancement Act, RSA 2000, c.E-12, as amended and Conservation and Reclamation Regulation (AR 115/93), as amended). Published by Alberta Queen's Printer.

ASPRS. 2014. ASPRS Positional Accuracy Standards for Digital Geospatial Data. Photogrammetric Engineering \& Remote Sensing 81(3): A1-A26. DOI:10.14358/PERS.81.3.A1-A26. 
Bell JC, Daniels WL, Zipper CE. 1989. The practice of 'approximate original contour' in the Central Appalachians. I. Slope stability and erosion potential. Landscape and Urban Planning 18: 127-138. DOI:10.1016/0169-2046(89)90004-2.

Beullens J, Van de Velde D, Nyssen J. 2014. Impact of slope aspect on hydrological rainfall and on the magnitude of rill erosion in Belgium and northern France. Catena 114: 129-139. DOI:10.1016/j.catena.2013.10.016.

Bird ECF, Dubois JP, Iltis J. 1984. The impacts of opencast mining on the rivers and coasts of New Caledonia, The United Nations University, http://archive.unu.edu/unupress/unupbooks/80505e/80505E00.htm [accessed 13 May 2017].

Blake GR. 1965. Bulk density. In: Black CA (Ed.), Methods of soil analyses. American Society of Agronomy, Madison, 374-390.

BOE. 2009. Real Decreto 975/2009, de 12 de junio, sobre gestión de los residuos de las industrias extractivas y de protección y rehabilitación del espacio afectado por actividades mineras. BOE núm. 143, de 13 de junio de 2009, 49948-49993 (BOE-A2009-984). Ministerio de la Presidencia, Madrid, España.

Brandt SA. 2000. Classification of geomorphological effects downstream of dams. Catena 40(4): 375-401. DOI:10.1016/S0341-8162(00)00093-X. 
Brenner FJ. 1985. Land reclamation after strip coal mining in the United States. Mining Magazine September: 211-217.

Carcavilla L, Ruiz R, Rodríguez E. 2008. Guía geológica del Parque Natural del Alto Tajo. Consejería de Medio Ambiente y Desarrollo Rural. Junta de Comunidades de Castilla-La Mancha.

CEDEX. 2004. CHAC, Cálculo Hidrometeorológico de Aportaciones y Crecidas. Centro de Estudios Hidrográficos, CEDEX. Ministerios de Fomento y de Medio Ambiente.

CNIG. 2004. Atlas Nacional de España. Sección II, Grupo 9. Climatología (2a Edición). Ministerio de Fomento. http://www.ign.es/ane/ane1986-2008/ [accessed 2 January 2017].

Coulthard TJ, Macklin MG, Kirkby MJ. 2002. A cellular model of Holocene upland river basin and alluvial fan evolution. Earth Surface Processes and Landforms 27(3): 269-288.DOI:10.1002/esp.318.

Chung F. 1974a. Quantitative interpretation of X-ray diffraction patterns of mixtures. I. Matrix-flushing method for quantitative multicomponent analysis. Journal of Applied Crystallography 7: 519-525.

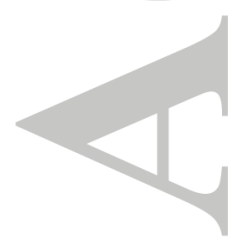


Chung F. 1974b. Quantitative interpretation of X-ray diffraction patterns of mixtures. II. Adiabatic. principle of X-ray diffraction analysis of mixture. Journal of Applied Crystallography 7: 526-531.

Dahlin T. 2001. The development of DC resistivity imaging techniques. Computer \& Geosciences 27(9): 1019-1029. DOI:10.1016/S0098-3004(00)00160-6.

Davis Instruments. 2005. Rain Collector II, Product Number: 7852. Rev B. Manual $(10 / 21 / 05)$

Dentith M, Mudge ST. 2014. Geophysics for the Mineral Exploration Geoscientist. Cambridge University Press.

DePriest N, Hopkinson LC, Quaranta JD, Michael PR, Ziemkiewicz PF. 2015. Geomorphic landform design alternatives for an existing valley fill in central Appalachia, USA: Quantifying the key issues. Ecological Engineering 81: 19-29. DOI:10.1016/j.ecoleng.2015.04.007.

DOCM. 2000. Law 1/2000, 6th April, Diario Oficial de Castilla-La Mancha DOCM, Vol. 43: 4413-4424.

Ehrenfeld JG. 2000. Defining the Limits of Restoration: The Need for Realistic Goals. Restoration Ecology, 8: 2-9. DOI:10.1046/j.1526-100x.2000.80002.x. 
Elliot WJ, Qiong W, Elliot AV. 1993. Application of the WEPP model to surface mine reclamation. Article presented at Challenge of Integrating Diverse Perspectives in Reclamation, 10th National Meeting, Spokane, Washington. American Society of Surface Mine Reclamation, 116-126.

Evans KG, Saynor MJ, Willgoose GR, Riley S.J. 2000. Post-mining landform evolution modelling: 1. Derivation of sediment transport model and rainfall-runoff model parameters. Earth Surface Processes and Landforms 25(7): 743-763. DOI:10.1002/1096-9837(200007)25:7<743::AID-ESP95>3.0.CO;2-0.

Evans MJ, Willgoose GR. 2000. Post-mining evolution landform modelling: 2. Effects of vegetation and surface ripping. Earth Surface Processes and Landforms 25(8): 803-823. DOI:10.1002/1096-9837(200008)25:8<803::AID-ESP96>3.0.CO;2-4.

Ferrari JR, Lookingbill TR, McCormick B, Townsend PA, Eshleman KN. 2009. Surface mining and reclamation effects on flood response of watersheds in the central Appalachian Plateau region, Water Resources Research. 45: W04407. DOI:10.1029/2008WR007109, 2009

Fifield JS. 2001. Designing for Effective Sediment and Erosion Control on Construction Sites. Forester Press.

Franks DM. 2015. Mountain Movers. Mining, Sustainability and the agents of change. Routledge, New York. 
García López A. 2012. Peñalén y sus yacimientos mineros. Las minas de Santa Engracia (1922-1937). La Encomienda de Peñalén, revista de la Asociación amigos de Peñalén 3: 4-7.

Garland GG, Olivier MJ. 1993. Predicting landslides from rainfall in a humid, subtropical region. Geomorphology 8(2-3): 165-173. DOI:10.1016/0169$555 \times(93) 90035-Z$.

GCD. 2014. Geomorphic Change Detection Software. Utah State University, Queen Mary University, North Arrow Research, ET-AL http://gcd.joewheaton.org/ [accessed 2 January 2017].

Gee GW, Bauder J.W. 1986. Particle-size Analysis. In: Page AL (Ed.). Methods of soil analysis, Part 1, Physical and mineralogical methods. Second Edition, Agronomy Monograph 9, American Society of Agronomy, Madison, WI, 383-411.

Goodman JM, Haigh MJ. 1981. Slope evolution on abandoned spoil banks in Eastern Oklahoma. Physical Geography 2(2): 160-173.

Hahn DT, Moldenhauer WC, Roth CB. 1985. Slope gradient effects on erosion of reclaimed soil. Transactions of the ASABE 28(3): 0805-0808. DOI:10.13031/2013.32342. 
Haigh, M.J. 1980. Slope retreat and gullying on revegetated surface mine dumps, Waun Hoscyn, Gwent. Earth Surface Processes 5(1): 77-79. DOI:10.1002/esp.3760050108.

Haigh, M.J. 1979. Ground retreat and slope evolution on regraded surface-mine dumps, Waunafon, Gwent. Earth Surface Processes 4(2): 183-189. DOI:10.1002/esp.3290040208.

Hancock GR, Crawter D, Fityus SG, Chandler J, Wells T. 2008. The measurement and modelling of rill erosion at angle of repose slopes in mine spoil. Earth Surface Processes and Landforms 33(7): 1006-1020. DOI: 10.1002/esp.1585.

Hancock GR, Loch RJ, Willgoose GR. 2003. The design of post-mining landscapes using geomorphic principles. Earth Surface Processes and Landforms 28(10): 10971110. DOI: $10.1002 /$ esp.518.

Hancock GR, Lowry JBC, Saynor MJ. 2016. Early landscape evolution - A field and modelling assessment for a post-mining landform. Catena 147: 669-708. DOI: 10.1016/j.catena.2016.08.015

Haering KC, Daniels WL, Galbraith JM. 2004. Appalachian Mine Soil Morphology and Properties: effects of Weathering and Mining Method. Soil Science Society of America Journal 68(4): 1315-1325 DOI:10.2136/sssaj2004.1315. 
Howard, EJ, Loch, RJ, Vacher, CA. 2011. Evolution of landform design concepts. Mining Technology. Trans. Inst. Mining and Metallurgy, 120: 112-117. DOI:10.1179/037178411X12942393517615.

ICONA. 1988. Agresividad de la lluvia en España. MAPA, Madrid.

IUSS Working Group WRB. 2007. World Reference Base for Soil Resources 2006, first update 2007. World Soil Resources Reports No. 103. FAO, Rome.

Kapolka NM, Dollhopf DJ. 2001. Effect of slope gradient and plant growth on soil loss on reconstructed steep slopes. International Journal of Surface Mining, Reclamation and Environment 15(2): 86-99. DOI: 10.1076/ijsm.15.2.86.3416.

Köppen W. 1918. Klassifikation der Klimate nach Temperatur, Niederschlag und Jahreslauf. Petermanns Mitt 64: 193-203.

Lindberg T, Bernhardt ES, Bier R, Helton AM, Merola RB, Vengosh A, Di Giulio RT. 2011. Cumulative impacts of mountaintop mining on an Appalachian watershed. Proceedings of the National Academy of Sciences, 108: 20929-20934. DOI:10.1073/pnas.1112381108

Loke MH, Barker RD. 1996. Rapid least-squares inversion of apparent resistivity pseudosections by a quasi-Newton method 1. Geophysical Prospecting 44(1): 131152. DOI:10.1111/j.1365-2478.1996.tb00142.x. 
López-Moreno JI, García-Ruiz JM. 2004. Influence of snow accumulation and snowmelt on streamflow in the central Spanish Pyrenees. Hydrological SciencesJournal-des

Sciences

Hydrologiques

49(5):

87-802.

DOI:10.1623/hysj.49.5.787.55135.

Losfeld G, L'Huillier L, Fogliani B, Jaffré T, Grison C. 2015. Mining in New

Caledonia: environmental stakes and restoration opportunities. Environmental Science and Pollution Research 22(8): 5592-5607. DOI: 10.1007/s11356-014-3358-x

MARM. 1997-2006. Mapa de Forestal de España Escala 1:50.000, Hoja 433 Atienza, Edición digital. Ministerio de Medio Ambiente, Medio Rural y Marino, Madrid. http://www.magrama.gob.es/es/biodiversidad/servicios/banco-datosnaturaleza/informacion-disponible/mfe50.aspx [accessed 2 January 2017].

Martín Duque JF, Sanz MA, Bodoque JM, Lucía A, Martín-Moreno C. 2010. Restoring earth surface processes through landform design. A 13-year monitoring of a geomorphic reclamation model for quarries on slopes. Earth Surface Processes and Landforms 35: 531-548. DOI:10.1002/esp.1950.

Martín Duque JF, Zapico I, Oyarzun R, López García JA, Cubas P. 2015. A descriptive and quantitative approach regarding erosion and development of landforms on abandoned mine tailings: New insights and environmental implications from SE Spain. Geomorphology 239: 1-16. DOI:10.1016/j.geomorph.2015.02.035. 
Martín-Moreno C. 2013. Cuantificación de la producción de sedimento en la zona minera del Parque Natural del Alto Tajo. PhD Dissertation. Complutense University of Madrid, Madrid.

Martín-Moreno C, Martín Duque JF, Nicolau lbarra JM, Hernando Rodríguez N, Sanz Santos MA, Sánchez Castillo L. 2016. Effects of topography and surface soil cover on erosion for mining reclamation: the experimental spoil heap at El Machorro Mine (Central Spain). Land Degradation and Development 27: 145-159. DOI:10.1002/ldr.2232.

Merino-Martín L, Moreno-de las Heras M, Pérez-Domingo S, Espigares T, Nicolau JM. 2012. Hydrological heterogeneity in Mediterranean reclaimed slopes: runoff and sediment yield at the patch and slope scales along a gradient of overland flow. Hydrology and Earth System Sciences 16(5): 1305-1320. DOI:10.5194/hess-161305-2012.

Miller AJ, Zégre NP. 2014. Mountaintop Removal Mining and Catchment Hydrology. Water 6: 472-499. DOI:10.3390/w6030472

Ministerio de Minería. 2011. Ley 20551, Regula el cierre de faenas e instalaciones mineras, Biblioteca del Congreso Nacional de Chile, http://www.sernageomin.cl/pdf/mineria/cierrefaena/01.Ley20.551.pdf $\quad$ (accessed October 25th, 2017) 
Minister of Public Works and Government Services Canada. 1996. The Minerals and Metals Policy of the Government of Canada. Partnerships for Sustainable Development. Catalogue no. M37-37/1996E. ISBN 0-662-25154-7

Moreno-de las Heras M, Espigares T, Merino-Martín L, Nicolau JM. 2011a. Waterrelated ecological impacts of rill erosion processes in Mediterranean-dry reclaimed slopes. Catena 84(3): 114-124. DOI:10.1016/j.catena.2010.10.010.

Moreno-de las Heras M, Díaz-Sierra R, Nicolau JM, Zavala MA. 2011b. Evaluating restoration of man-made slopes: a threshold approach balancing vegetation and rill erosion. Earth Surface Processes and Landforms 36(10): 1367-1377. DOI:10.1002/esp.2160.

Mossa J, James LA. 2013. Impacts of mining on geomorphic systems. In: Shroder J. (Editor in chief), James LA, Harden CP, Clague JJ. (Eds.), Treatise on Geomorphology. Academic Press, San Diego, CA, vol. 13, Geomorphology of Human Disturbances, Climate Change, and Natural Hazards.

Mudd GM, Boger DV. 2013. The ever growing case for paste and thickened tailings: Towards more sustainable mine waste management. AusIMM Bulletin, April, 56-59.

Muñoz Martín A, Olaiz A, de Vicente G, Antón L, Elorza FJ, de Vicente R. 2007. Análisis de la geometría en profundidad de fracturas conductoras en zonas de baja permeabilidad mediante tomografía eléctrica (El berrocal, Sistema Central Español). Geogaceta 42: 35-38. 
Nearing MA, Foster GR, Lane LJ, Finkner SC. 1989. A process-based soil erosion model for USDA: water erosion prediction project technology. Transactions of ASAE 32: 1587-1593.

Netherlands Normalisation Institute. 1994. NEN 5754:1994 Determination of organic matter content in soil as loss-on-ignition.

Nicolau JM. 2003. Trends in relief design and construction in opencast mining reclamation. Land Degradation and Development 14: 215-226. DOI:10.1002/ldr.548.

NMMMD. 2010. A Method for the Evaluation of Compliance with the Approximate Original Contour Requirements of CSMC RULE 19.8. NMAC. New Mexico Mining and Minerals Division, Santa Fe. http://www.emnrd.state.nm.us/MMD/documents/AOCGuidelines.pdf $\quad$ [accesed 15 October 2016].

Nyssen J, Vermeerch D. 2010. Slope aspect affects geomorphic dynamics of coal mining spoil heaps in Belgium. Geomorphology 123: 109-121. DOI:10.1016/j.geomorph.2010.07.004.

Olmo P, Álvaro M. 1989. Mapa Geológico de España, Escala 1:50.000. 2ª Serie (MAGNA), Peralejos de las Truchas (539). IGME, Servicio de Publicaciones: Madrid. 
Orman M, Peevers R, Sample K. 2011. Waste Piles and Dumps. In SME Mining Engineering Handbook, Darling P, (ed) SME: Englewood, CO, USA; 667-680.

Palmer MA, Bernhardt ES, Schlesinger WH, Eshleman KN, Foufoula-Georgiou E, Hendryx MS, Lemly AD, Likens GE, Loucks OL, Power ME, White PS, Wilcock PR. 2010. Mountaintop Mining Consequences. Science 237: 148-149. DOI: 10.1126/science. 1180543 .

Phillips JD. 2004. Impacts of surface mine valley fills on headwater floods in eastern Kentucky. Environmental Geology 45: 367-380. DOI: 10.1007/s00254-003-0883-1

Pickup G. 2001. Geomorphic processes in the Ok Tedi and Fly river system: current status, future trends and rehabilitation. Report to environment section Ok Tedi Mining Ltd.

PNOA. 2009. Plan Nacional de Ortofotografía Aérea, LiDAR de Castilla La-Mancha, vuelo de 2009. Instituto Geográfico Nacional, Ministerio de Fomento. http://pnoa.ign.es/ [In Spanish, accessed 6 December 2016].

Porta J, López-Acevedo Reguerín M, Roquero de Laburu C. 1999. Edafología para la agricultura y el medio ambiente. Mundi-Prensa, Madrid.

Rey Benayas JM, Martins A, Nicolau JM, Schulz J. 2007. Abandonment of agricultural land: an overview of drivers and consequences. CAB Reviews: 
Perspectives in Agriculture, Veterinary Science, Nutrition and Natural Resources, 2: 1-15. DOI:10.1079/PAVSNNR20072057.

Reynolds JM. 2011. An introduction to applied and environmental geophysics, John Wiley \& Sons (2nd Edition).

Riley SJ. 1995. Geomorphic estimates of the stability of a uranium mill tailings containment cover, Nabarlek, NT, Australia. Land Degradation and Rehabilitation 6(1): 1-16. DOI:10.1002/ldr.3400060102.

Rosewell CJ, Edwards K. 1988. SOILOSS: a program to assist in the selection of management practices to reduce soil erosion. Technical handbook № 11, Soil Conservation Service of New South Wales, Sydney.

Sawatsky L, McKenna G, Keys MJ, Long D. 2000. Towards minimising the long-term liability of reclaimed mined sites. In Reclaimed Land: Erosion Control, Soils and Ecology, Haigh MJ (ed). Balkema, Rotterdam; 21-36.

Schaffrath KR, Belmont P, Wheaton JM. 2015. Landscape-scale geomorphic change detection: Quantifying spatially variable uncertainty and circumventing legacy data issues. Geomorphology 250: 334-348.

SMCRA. 1977. The Surface Mining Control and Reclamation Act of 1977. Public law, 95-87 . Statutes at Large, 91 Stat. 445. Federal Law. United States. 
So HB, Yatapange K, Horn CP. 2002. Mine-Erosion: an integrated erosion and landscape design package for monitoring and modelling erosion from steep hillslopes on minespoils. 12th ISCO Conference, Beijing.

So HB, Aylmore LAG. 1993. How do sodic soils behave - the effects of sodicity on soil physical behavior. Soil Research 31: 761-777. DOI:10.1071/SR9930761

Toy TJ, Foster GR. 1998. Guidelines for the Use of the Revised Universal Soil Loss Equation on Mined Lands, Construction Sites, and Reclaimed Lands. Office of Surface Mining, Reclamation and Enforcement, Denver.

Urbano Terrón P. 1995. Tratado de fitotecnia general. Mundi-Prensa, Madrid.

Van Niekerk HJ, Viljoen MJ. 2005. Causes and consequences of the Merriespruit and other tailings-dam failures. Land Degradation and Development 16: 201-212. DOI:10.1002/ldr.681.

Villavicencio G, Espinace R, Palma J, Fourie A, Valenzuela P. 2014. Failures of sand tailings dams in a highly seismic country. Canadian Geotechnical Journal 51(4): 449-464.DOI:10.1139/cgj-2013-0142.

West TO, Wali MK. 1999. A model for estimating sediment yield from surface-mined lands. International Journal of Surface Mining Reclamation and Environment 13(3): 103-109. DOI:10.1080/09208119908944225. 
Wheaton JM, Brasington J, Darby SE, Sear DA. 2010. Accounting for uncertainty in DEMs from repeat topographic surveys: improved sediment budgets. Earth Surface Processes and Landforms 35: 136-156. DOI:10.1002/esp.1886.

Willgoose GR, Bras RL, Rodriguez-Iturbe I. 1989. Modelling of the erosional impacts of land use change: A new approach using a physically based catchment evolution model. In: Hydrology and Water Resources Symposium 1989, Christchurch NZ, National Conference publication № 89/19, The Institute of Engineers Australia, Melbourne; 325-329.

Williams JR. 1975. Sediment Yield Prediction with Universal Equation Using Runoff Energy Factor, U.S. Department of Agriculture. Agricultural Research Service (A.R.S.), U.S.A. Department of Agriculture, 244-252.

Wohl E. 2006. Human impacts to mountain streams. Geomorphology 79(3-4): 217248. DOI:10.1016/j.geomorph.2006.06.020.

Zipper CE, Daniels WL, Bell JC. 1989. The practice of 'approximate original contour' in the central Appalachians. II. Economic and environmental consequences of an alternative. Landscape and Urban Planning 18: 139-152. DOI:10.1016/01692046(89)90005-4. 
Table 1 Some catastrophes associated to landform instability in mountainous areas

\begin{tabular}{|c|c|}
\hline Reported incidence and details & Reference \\
\hline $\begin{array}{l}\text { The negligent design of a coal waste dump triggered a collapse that } \\
\text { killed } 116 \text { children and } 28 \text { adults (Aberfan, Wales) }\end{array}$ & $\begin{array}{l}\text { Van Niekerk and Viljoen } \\
\text { (2005) }\end{array}$ \\
\hline $\begin{array}{l}\text { Compilation of failures of tailings dams in the Andes Cordillera due to } \\
\text { seismicity (Chile) }\end{array}$ & Villavicencio et al. (2014) \\
\hline $\begin{array}{l}\text { Perturbations on water flows and dramatic soil erosion lead to metal- } \\
\text { rich sediment transport downstream into rivers and lagoon, due to } \\
\text { nickel mountain mining (New Caledonia) }\end{array}$ & $\begin{array}{l}\text { Bird et al. (1984); Losfeld } \\
\text { et al. (2015) }\end{array}$ \\
\hline $\begin{array}{l}\text { Tailings dam failure at Ok Tedi mine and subsequent disposal of } \\
\text { tailings into the Fly river (Papua New Guinea) }\end{array}$ & $\begin{array}{l}\text { Franks (2015); Pickup } \\
\text { (2001) }\end{array}$ \\
\hline $\begin{array}{l}\text { Tailings dam failure polluting the ocean (Placer Dome's mine, } \\
\text { Marinduque island, Philippines) }\end{array}$ & Franks (2015) \\
\hline
\end{tabular}


Table 2 The issue of landform stability as reflected in the mine reclamation regulations of different countries

\begin{tabular}{|c|c|c|}
\hline Country & Landform requirements & Reference \\
\hline \multirow[t]{3}{*}{ Australia } & $\begin{array}{l}\text { Western Australia require safe, stable, non-polluting post- } \\
\text { mining landforms. }\end{array}$ & $\begin{array}{l}\text { In: Howard et al. (2011, p. } \\
112)\end{array}$ \\
\hline & $\begin{array}{l}\text { Queensland - rehabilitated areas are required to be safe for } \\
\text { humans and wildlife, non-polluting, stable, and able to } \\
\text { sustain an agreed post-mining land use }\end{array}$ & \\
\hline & $\begin{array}{l}\text { New South Wales: stable and permanent landforms that are } \\
\text { suitable for the agreed end land use, that will not adversely } \\
\text { affect surrounding land, and with maintenance needs no } \\
\text { greater than the surrounding land. }\end{array}$ & \\
\hline \multirow[t]{2}{*}{ Canada } & $\begin{array}{l}\text { Achieve a viable and wherever practicable, self-sustaining, } \\
\text { ecosystem that is compatible with a healthy environment and } \\
\text { other human activities }\end{array}$ & $\begin{array}{l}\text { Minister of Public Works and } \\
\text { Government Services of } \\
\text { Canada (1966, p. 14) }\end{array}$ \\
\hline & $\begin{array}{l}\text { Until self-sustaining vegetation cover is established, erosion } \\
\text { control methods are necessary and include, among others, } \\
\text { slope stabilization... (p. 10) and ... will avoid unstable or } \\
\text { steep slopes adjacent to watercourses or water bodies ( } p \text {. } \\
\text { 20) }\end{array}$ & $\begin{array}{l}\text { Alberta Government (2005, p. } \\
10 \text { and 20) }\end{array}$ \\
\hline Chile & $\begin{array}{l}\text { Guarantee the physical and chemical stability of the sites } \\
\text { where the extractive activities take place }\end{array}$ & $\begin{array}{l}\text { Ministerio de Minería, Ley } \\
20551 \text { (2011, several pages) }\end{array}$ \\
\hline \multirow[t]{2}{*}{ USA } & $\begin{array}{l}\text { The reclaimed area, including any terracing or access roads, } \\
\text { closely resembles the general surface configuration of the } \\
\text { land prior to mining and blends into and complements the } \\
\text { drainage pattern of the surrounding terrain... }\end{array}$ & SMCRA $(1977$, p. 114) \\
\hline & $\begin{array}{l}\text { Provide a topography capable of stabilizing the surface from } \\
\text { excessive erosion...minimizing off-site effects and changes } \\
\text { to the prevailing hydrologic balance }\end{array}$ & $\operatorname{NMMMD}(2010$, p. 4) \\
\hline Spain & $\begin{array}{l}\text { Ensuring the stability of the waste and prevention of soil and } \\
\text { water (surface and groundwater) pollution }\end{array}$ & $\begin{array}{l}\text { RD975/2009, BOE (2009, } \\
\text { several pages) }\end{array}$ \\
\hline
\end{tabular}


Table 3 Characteristics of the Electrical Resistivity Tomography (ERT) profiles performed at the storage areas of check dam \#1 (CD \#1) and \#2 (CD \#2).

\begin{tabular}{|c|c|c|c|c|c|}
\hline \multicolumn{2}{|c|}{$\begin{array}{c}\text { ERT } \\
\text { profiles }\end{array}$} & \multirow{2}{*}{$\begin{array}{c}\begin{array}{c}\text { Number of } \\
\text { electrodes }\end{array} \\
18\end{array}$} & \multirow{2}{*}{$\begin{array}{c}\begin{array}{c}\text { Length } \\
\text { (m) }\end{array} \\
42.5\end{array}$} & \multirow{2}{*}{$\begin{array}{c}\begin{array}{c}\text { Levels of } \\
\text { investigation }\end{array} \\
9\end{array}$} & \multirow{2}{*}{$\begin{array}{c}\begin{array}{c}\text { Depth } \\
\text { reached }(\mathrm{m})\end{array} \\
8\end{array}$} \\
\hline$ت$ & ERT 1 & & & & \\
\hline ○ & ERT 2 & 32 & 77.5 & 12 & 11 \\
\hline \multirow{3}{*}{$\begin{array}{l}\# \\
0\end{array}$} & ERT 3 & 35 & 85 & 14 & 13 \\
\hline & ERT 4 & 48 & 117.5 & 14 & 14 \\
\hline & ERT 5 & 16 & 37.5 & 7 & 7 \\
\hline
\end{tabular}

This article is protected by copyright. All rights reserved. 
Table 4 Topography and substrata physico-chemical properties of the three waste dumps. Mean \pm standard deviation values are shown. Number of samples $=3$.

\begin{tabular}{|c|c|c|c|c|}
\hline & \multirow{2}{*}{ Units } & \multicolumn{3}{|c|}{ Waste dump } \\
\hline & & A & B & C \\
\hline \multicolumn{5}{|l|}{ Topography } \\
\hline Maximum slope length & $\mathrm{m}$ & 127 & 91 & 50 \\
\hline Slope gradient (mean) & $\%$ & 55 & 60 & 58 \\
\hline Area & ha & 2.64 & 1.34 & 1.11 \\
\hline \multicolumn{5}{|l|}{ Substrata characteristics } \\
\hline & \multirow{7}{*}{$\%$} & quartz $71.0 \pm 3.6$ & quartz $69.7 \pm 11.8$ & quartz $71.0 \pm 8.7$ \\
\hline \multirow{6}{*}{ Mineralogy } & & kaolinite $9.3 \pm 3.2$ & kaolinite $20.3 \pm 15.0$ & kaolinite $16.3 \pm 3.2$ \\
\hline & & calcite $7.3 \pm 9.3$ & calcite $1.7 \pm 2.1$ & calcite $1.7 \pm 1.2$ \\
\hline & & dolomite $2.0 \pm 1.0$ & dolomite $2.7 \pm 0.0$ & dolomite $1.0 \pm 0.0$ \\
\hline & & ankerite $2.3 \pm 2.5$ & mica/illite $4.0 \pm 3.5$ & plagioclase $2.0 \pm 2.0$ \\
\hline & & mica/illite $4.3 \pm 1.5$ & K-feldspar $1.3 \pm 0.0$ & mica/illite $6.3 \pm 5.9$ \\
\hline & & K-feldspar $3.7 \pm 0.0$ & hematite $0.3 \pm 0.0$ & $\begin{array}{c}\text { K-feldspar } 1.3 \pm 0.0 \\
\text { hematite } 0.3 \pm 0.0\end{array}$ \\
\hline Clay $(<0.002 \mathrm{~mm})$ & $\%$ & $16.2 \pm 0.05$ & $12.3 \pm 0.03$ & $12.4 \pm 0.03$ \\
\hline Silt (0.002 - 0.02 mm) & $\%$ & $11.3 \pm 0.01$ & $7.9 \pm 0.03$ & $12.7 \pm 0.04$ \\
\hline Fine sand $(0.02-0.2 \mathrm{~mm})$ & $\%$ & $31.1 \pm 0.06$ & $31.5 \pm 0.05$ & $32.8 \pm 0.06$ \\
\hline Medium sand $(0.2-0.5 \mathrm{~mm})$ & $\%$ & $19.4 \pm 0.03$ & $23.5 \pm 0.05$ & $21.1 \pm 0.05$ \\
\hline Coarse sand $(0.5-2 \mathrm{~mm})$ & $\%$ & $22.0 \pm 0.03$ & $24.8 \pm 0.05$ & $21.0 \pm 0.06$ \\
\hline Texture & USDA & Sandy loam & Sandy loam & Sandy loam \\
\hline Bulk density & $\mathrm{g} \mathrm{cm}^{-3}$ & $1.55 \pm 0.07$ & $1.57 \pm 0.11$ & $1.50 \pm 0.13$ \\
\hline $\mathrm{pH}$ & & $8.63 \pm 0.09$ & $8.91 \pm 0.06$ & $8.75 \pm 0.12$ \\
\hline Sodium content (in solution) & $\mu g g^{-1}$ & $76.0 \pm 3.5$ & $89.3 \pm 23.6$ & $6.6 \pm 2.8$ \\
\hline Electrical Conductivity (EC) & $d S m^{-1}$ & $0.09 \pm 0.04$ & $0.06 \pm 0.01$ & $0.06 \pm 0.00$ \\
\hline Organic Matter (OM) & $\%$ & $0.43 \pm 0.17$ & $0.37 \pm 0.11$ & $0.40 \pm 0.06$ \\
\hline
\end{tabular}

This article is protected by copyright. All rights reserved. 
Table 5 Volume and mass of sediment eroded at the waste dumps of Santa Engracia mine since its regrading, $1990-2009$, for a minLoD $= \pm 28 \mathrm{~cm}$. It also includes the calculated error, the total values, the sediment yield of each waste dump and weighted mean annual sediment yield*.

\begin{tabular}{|c|c|c|c|c|c|c|}
\hline Waste dump & $\begin{array}{c}\text { Area } \\
\text { (ha) }\end{array}$ & $\begin{array}{c}\text { Area of } \\
\text { detectable } \\
\text { change } \\
\text { (ha) }\end{array}$ & $\begin{array}{l}\text { Volume of } \\
\text { eroded } \\
\text { waste }\left(\mathbf{m}^{3}\right)\end{array}$ & $\begin{array}{c}\text { Error } \\
(\%)\end{array}$ & $\begin{array}{l}\text { Mass of } \\
\text { eroded waste } \\
(\mathrm{Mg})\end{array}$ & $\begin{array}{c}\text { Annual } \\
\text { erosion- } \\
\text { sediment yield } \\
\left(\mathrm{Mg} \mathrm{ha}^{-1} \mathrm{yr}^{-1}\right) \\
\end{array}$ \\
\hline A & 2.64 & 1.04 & $10886 \pm 2827$ & \pm 26 & $16764 \pm 4354$ & $334 \pm 87$ \\
\hline B & 1.34 & 0.58 & $7827 \pm 1649$ & \pm 21 & $12054 \pm 2539$ & $473 \pm 100$ \\
\hline $\mathrm{C}$ & 1.11 & 0.54 & $3455 \pm 1513$ & \pm 44 & $5321 \pm 2330$ & $252 \pm 110$ \\
\hline Total & 5.09 & 2.16 & $22168 \pm 5989$ & & $34139 \pm 9223$ & $353 \pm 95^{\star}$ \\
\hline
\end{tabular}

This article is protected by copyright. All rights reserved. 
Table 6 Volume and mass of sediment trapped by check dams.

\begin{tabular}{ccccc}
\hline \multirow{2}{*}{$\begin{array}{c}\text { Check } \\
\text { dam }\end{array}$} & \multicolumn{2}{c}{ Total (1981-2012) } & \multicolumn{2}{c}{ Period 2009-2010 } \\
\cline { 2 - 5 } & $\begin{array}{c}\text { Volume of } \\
\text { sediments } \\
\left(\mathbf{m}^{\mathbf{3}}\right)\end{array}$ & $\begin{array}{c}\text { Mass of } \\
\text { sediments } \\
(\mathbf{M g})\end{array}$ & $\begin{array}{c}\text { Volume of } \\
\text { sediments } \\
\left(\mathbf{m}^{3}\right)\end{array}$ & $\begin{array}{c}\text { Mass of } \\
\text { sediments } \\
(\mathbf{M g})\end{array}$ \\
\hline$\# 1$ & $2700 \pm 140$ & $4200 \pm 210$ & $1100 \pm 60$ & $1700 \pm 90$ \\
$\# 2$ & $10300 \pm 520$ & $16200 \pm 810$ & $3000 \pm 150$ & $4700 \pm 240$ \\
Total & $\mathbf{1 3 0 0 0 \pm 6 6 0}$ & $\mathbf{2 0 4 0 0 \pm 1 0 2 0}$ & $\mathbf{4 1 0 0 \pm 2 1 0}$ & $\mathbf{6 4 0 0 \pm 3 3 0}$ \\
\hline
\end{tabular}
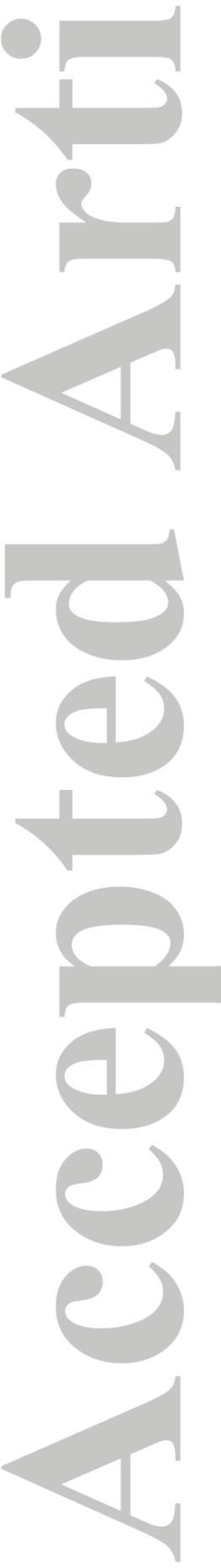

This article is protected by copyright. All rights reserved. 
Table 7 Comparison of waste dump sediment yield obtained in this study with sediment yields measured at other mine sites. The values of erosion rates refer to mean values or value ranges published in each case. The values in bold were calculated using a density of $1.5 \mathrm{~g} \mathrm{~cm}^{-3}$, the mean for sandy soils (Porta et al., 1999). ${ }^{* *}=$ published value coincides with that shown in the sediment yield column

\begin{tabular}{|c|c|c|c|c|c|}
\hline Study site & $\begin{array}{l}\text { Description - } \\
\text { Study scale }\end{array}$ & Methodology & $\begin{array}{l}\text { Published } \\
\text { values }\end{array}$ & $\begin{array}{c}\text { Calculated } \\
\text { values. } \\
\text { Sediment yield } \\
\left(\mathrm{Mg} \mathrm{ha}^{-1} \mathrm{yr}^{-1}\right)\end{array}$ & Sources \\
\hline $\begin{array}{l}\text { Santa Engracia } \\
\text { mine, Peñalén } \\
\text { (Guadalajara, } \\
\text { Spain) }\end{array}$ & $\begin{array}{l}\text { Terraced waste } \\
\text { dumps built on } \\
\text { overburden } \\
\text { materials }\end{array}$ & DoD & ** & $353 \pm 95$ & This study \\
\hline $\begin{array}{l}\text { AMAX Ayrshire } \\
\text { Mine, Evansville, } \\
\text { Indiana (EEUU) }\end{array}$ & $\begin{array}{l}\text { Relationship } \\
\text { between gradient } \\
\text { slope and erosion }\end{array}$ & $\begin{array}{l}\text { Rainfall } \\
\text { simulations in } \\
\text { erosion parcels }\end{array}$ & $\begin{array}{l}67.8 \mathrm{Mg} \mathrm{ha}^{-1} \\
117.7 \mathrm{Mg} \mathrm{ha}^{-1} \\
144.3 \mathrm{Mg} \mathrm{ha}^{-1}\end{array}$ & $\begin{array}{l}- \\
- \\
-\end{array}$ & $\begin{array}{l}\text { Hahn et al. } \\
\text { (1985) }\end{array}$ \\
\hline $\begin{array}{l}\text { Eastern Oklahoma } \\
\text { (EEUU) }\end{array}$ & $\begin{array}{l}\text { Slope or ground } \\
\text { retreat on } \\
\text { abandoned spoil } \\
\text { banks }\end{array}$ & Erosion pins & $\begin{array}{l}7,6-9,5 \\
\mathrm{~mm} \mathrm{yr}^{-1}\end{array}$ & $160-180$ & $\begin{array}{l}\text { Goodman and } \\
\text { Haigh (1981) }\end{array}$ \\
\hline $\begin{array}{l}\text { Gallia County, Ohio } \\
\text { (EEUU) }\end{array}$ & $\begin{array}{l}\text { Abandoned waste } \\
\text { dumps. Sandy soil }\end{array}$ & Erosion parcels & ** & 203 & West and Wali \\
\hline $\begin{array}{l}\text { Ohio County, } \\
\text { Kentucky (EEUU) }\end{array}$ & $\begin{array}{l}\text { Terraced waste } \\
\text { dumps. Subsoil. }\end{array}$ & & ** & 116 & \\
\hline $\begin{array}{l}\text { Kidston Gold Mine, } \\
\text { North Queensland } \\
\text { (Australia) }\end{array}$ & $\begin{array}{l}\text { Slope scale. Waste } \\
\text { dumps without } \\
\text { vegetation cover. }\end{array}$ & Erosion parcels & ** & 425 & $\begin{array}{l}\text { So et al. } \\
\text { (2002) }\end{array}$ \\
\hline $\begin{array}{l}\text { San Cristóbal- } \\
\text { Perules mining, } \\
\text { Mazarrón } \\
\text { (Southeast Spain) }\end{array}$ & $\begin{array}{l}\text { Terraced slope of a } \\
\text { tailings dam }\end{array}$ & DoD & ** & 152 & $\begin{array}{l}\text { Martín Duque } \\
\text { et al. (2015) }\end{array}$ \\
\hline $\begin{array}{l}\text { El Machorro mine, } \\
\text { Guadalajara (East- } \\
\text { Central Spain) }\end{array}$ & $\begin{array}{l}\text { Linear slope built } \\
\text { with overburden } \\
\text { (sandy materials) }\end{array}$ & $\begin{array}{l}\text { Erosion parcels } \\
\text { with sediment } \\
\text { fences }\end{array}$ & ** & 347 & $\begin{array}{l}\text { Martín-Moreno } \\
\text { et al. (2016) }\end{array}$ \\
\hline
\end{tabular}




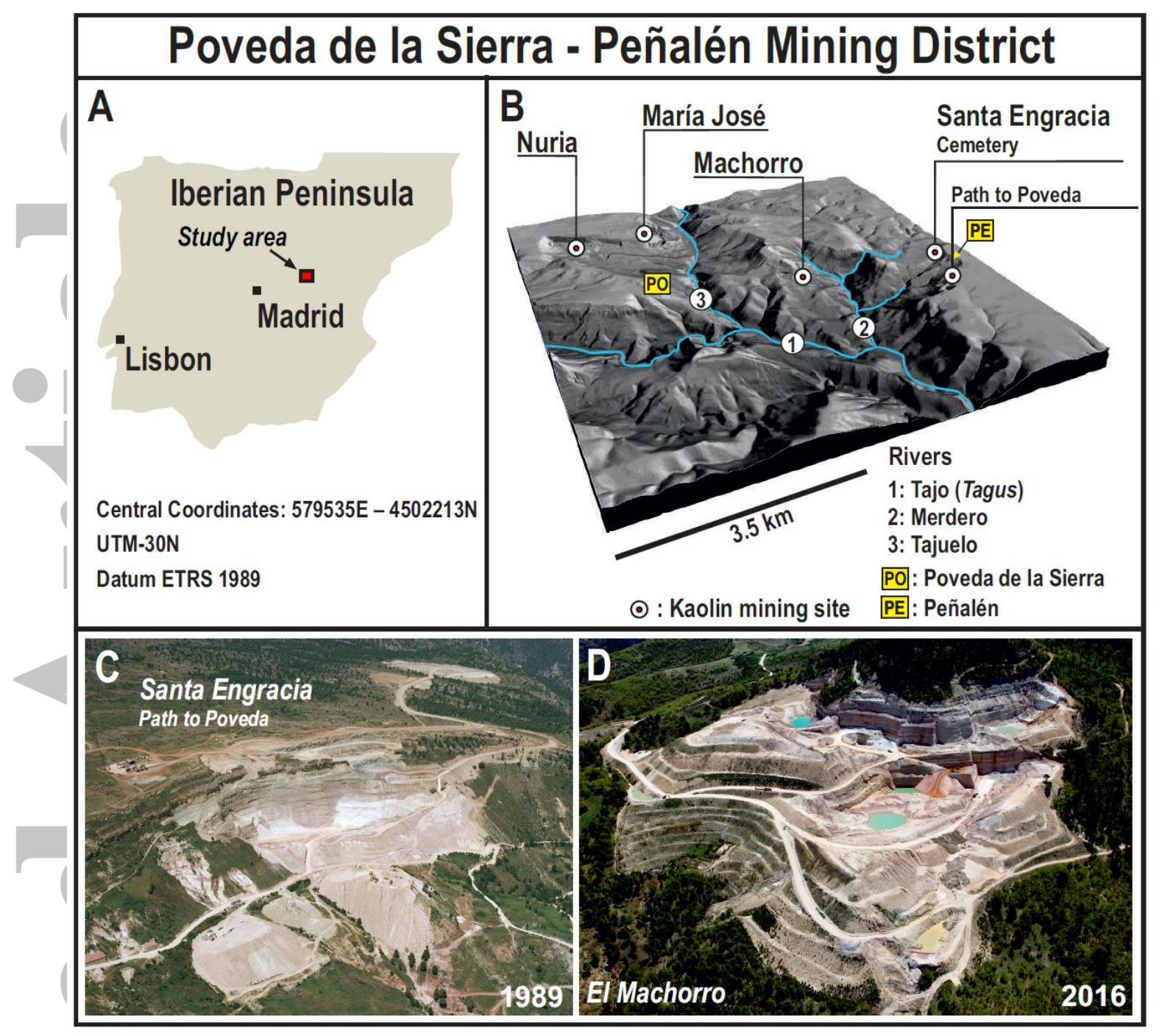

Figure 1 A) Study area - Poveda de la Sierra - Peñalén Mining District location on the lberian Peninsula; B) 3D model showing the physiographic setting of the five main mined sites; C) General view of the Santa Engracia mine (Path to Poveda site) in 1989; and D) General view of El Machorro mine in 2016. For C and D, note the similitude of this type of mining with the Mountaintop Mining (MTM) in the Appalachian Mountains in the eastern United States.

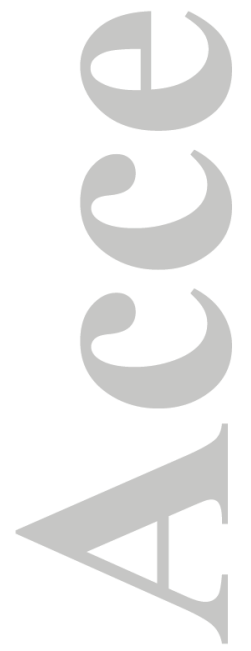

This article is protected by copyright. All rights reserved. 


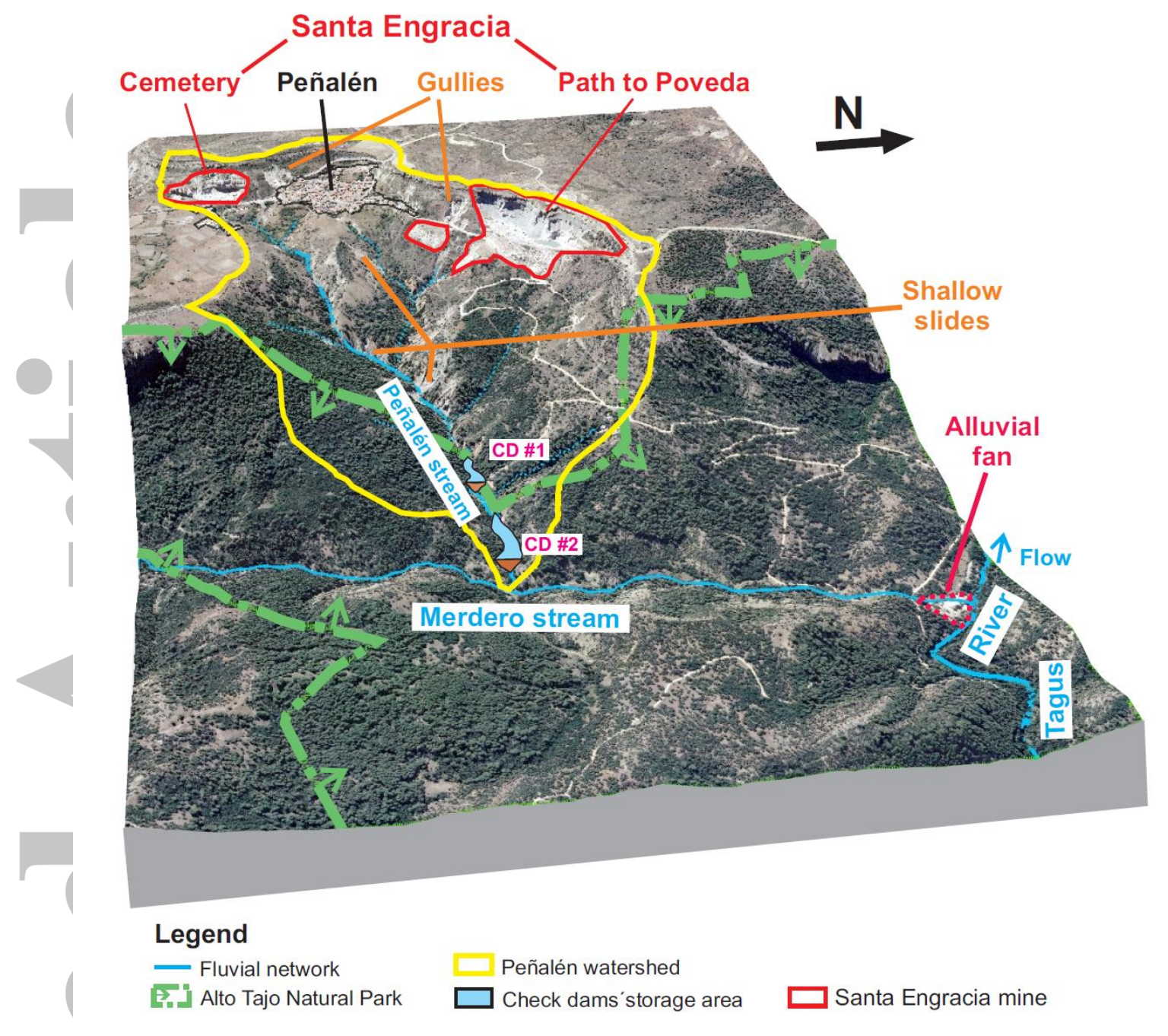

Figure 2 Peñalén watershed. CD = check dam. The Alto Tajo Natural Park lands are downslope of the green line, towards the Tagus River. 


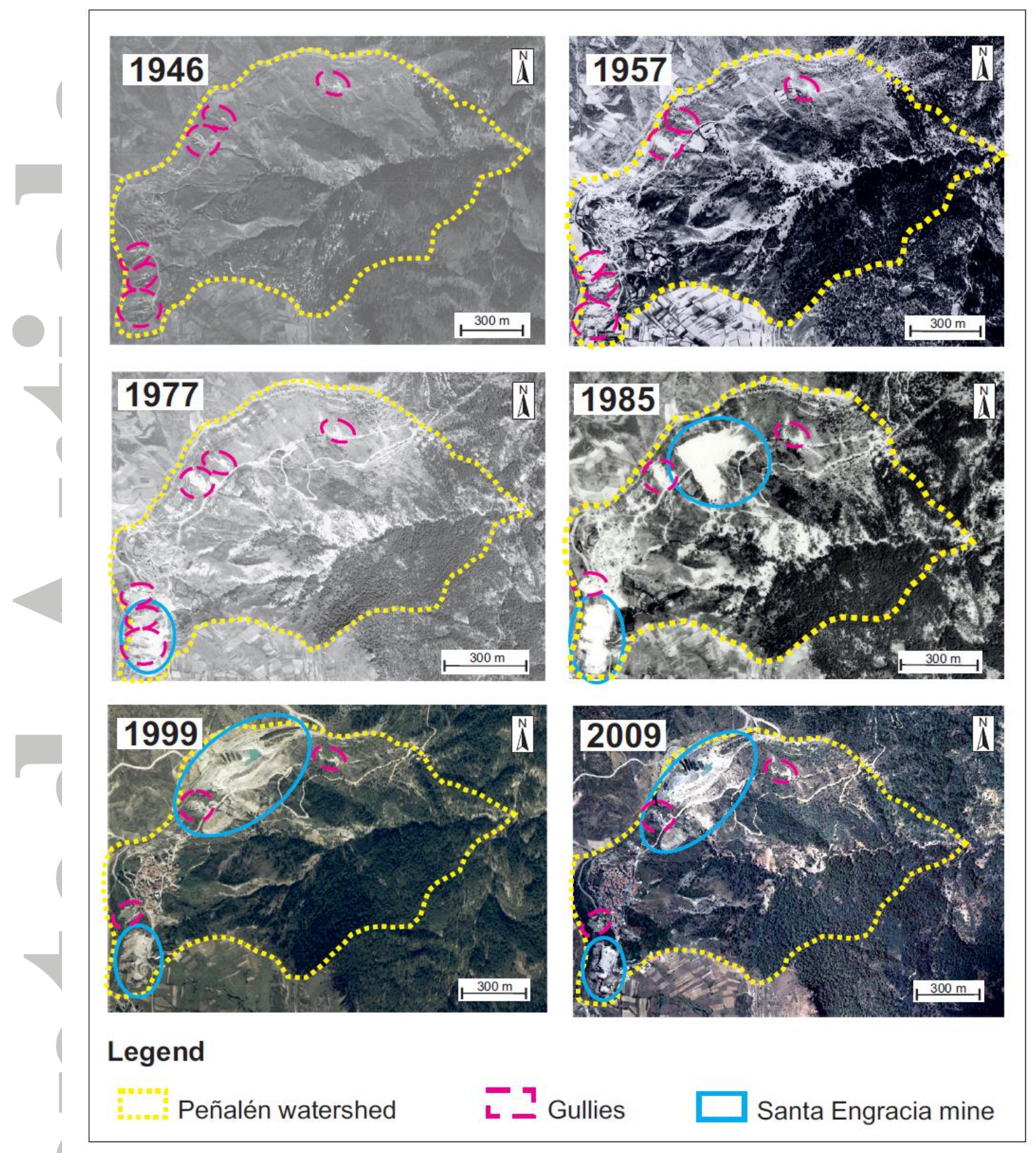

Figure 3 Aerial photographs of the Peñalén watershed from 1946 to 2009. Both the vegetation cover and the mined sites have increased with time (see specifically aerial photographs from 1985 to 2009). Photograph sources: 1946 and 1957, Centro Cartográfico y Geográfico del Ejército del Aire (CECAF); 1977, 1985 and 1999, Instituto Geográfico Nacional (IGN); and 2009 Plan Nacional de Ortofotografía Aérea (PNOA) Ministerio de Fomento, Instituto Geográfico Nacional, (IGN) and Centro Nacional de Información Geográfica,(CNIG). The photographs are not georeferenced and show therefore some deformation. Central coordinates 579535E; $4502213 \mathrm{~N}$, coordinate system UTM-30N, datum ETRS 1989). 


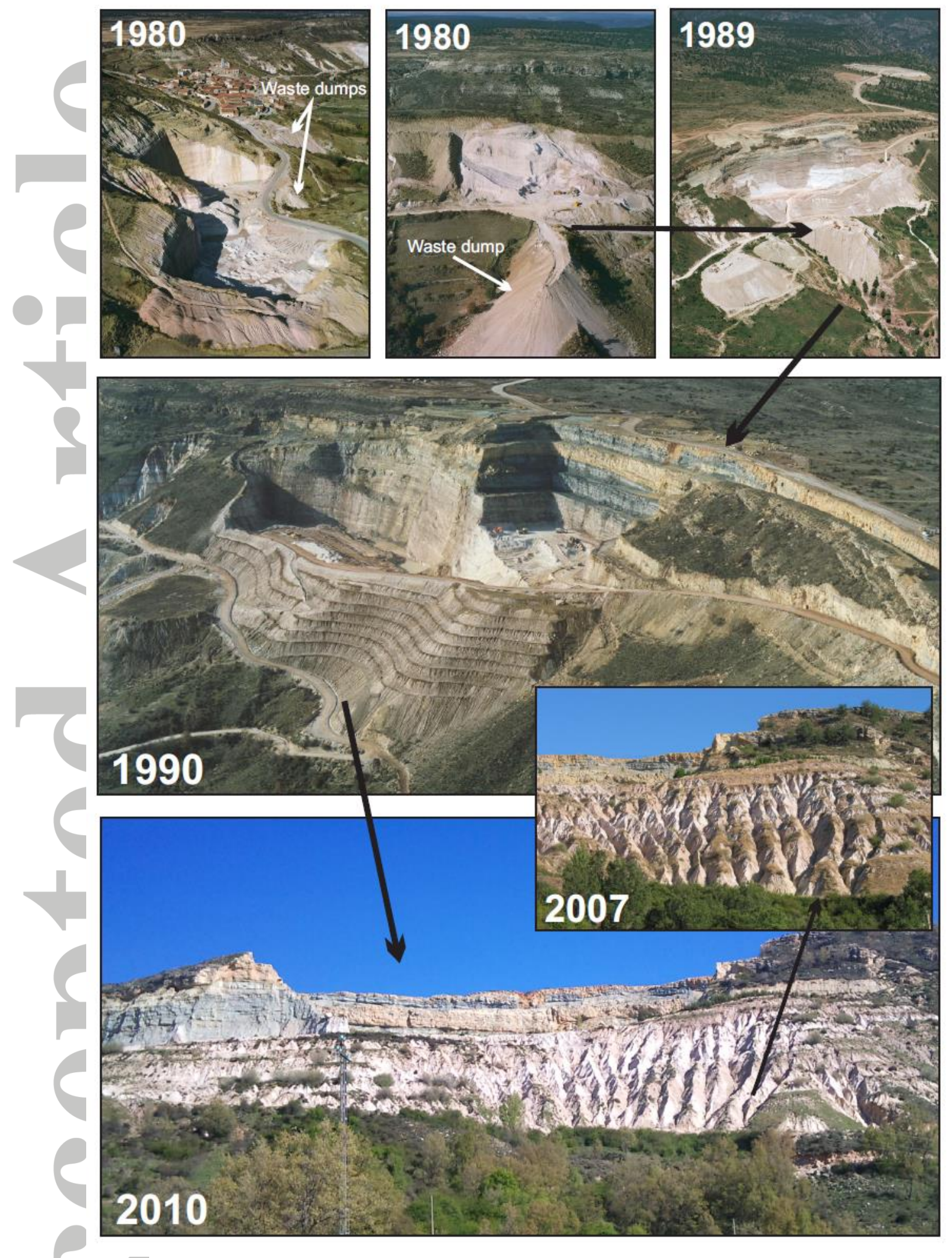

Figure 4 Santa Engracia mine, Path to Poveda site, oblique aerial photos, and ground pictures, spanning 30 years. In 1980, mining operations were active, and the process of outslope waste dumping can be clearly seen. In 1990 the waste dumps were slightly regraded, conforming a terraced topography, which eroded into a network of gullies (2010). 1980, 1989 and 1990 oblique aerial photos by Paisajes Españoles S.A. 


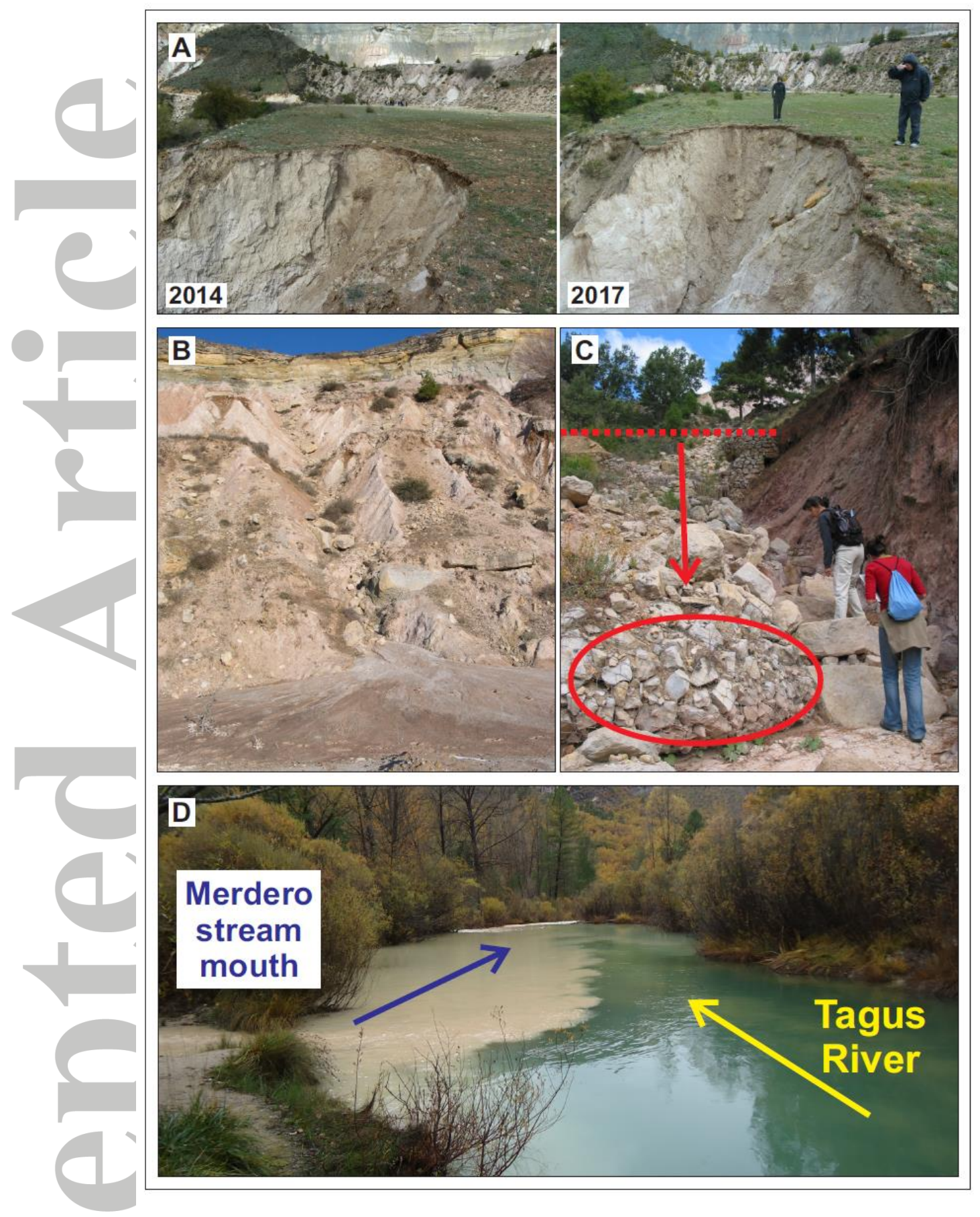

Figure 5 Erosional and sedimentation landforms denoting very active processes at the Santa Engracia waste dumps. A) Gully head retreat the waste dump B (see figure 6 for specific location). B) Detail of typical erosional and sedimentation landforms at waste dump A (see figure 6 for specific location): straight gully cutting through the whole dump with an active alluvial fan at the toe. C) A 2-m high check dam broken by a debris flow process, forming a debris cone (ellipse, which includes part of the dam); the dotted line shows the former position of the check dam, and the arrow shows the check dam displacement. D) The Merdero stream emitting sediment into the Tagus River after a rainfall event, which main sources of sediment are the Santa Engracia mined sites, once the check dams are totally filled; Figure 2 shows the location of mined sites, check dams, drainage network and watersheds, and precise location of photo 5D, downstream of the alluvial fan formed when the Merdero stream debouches into the Tagus River. 


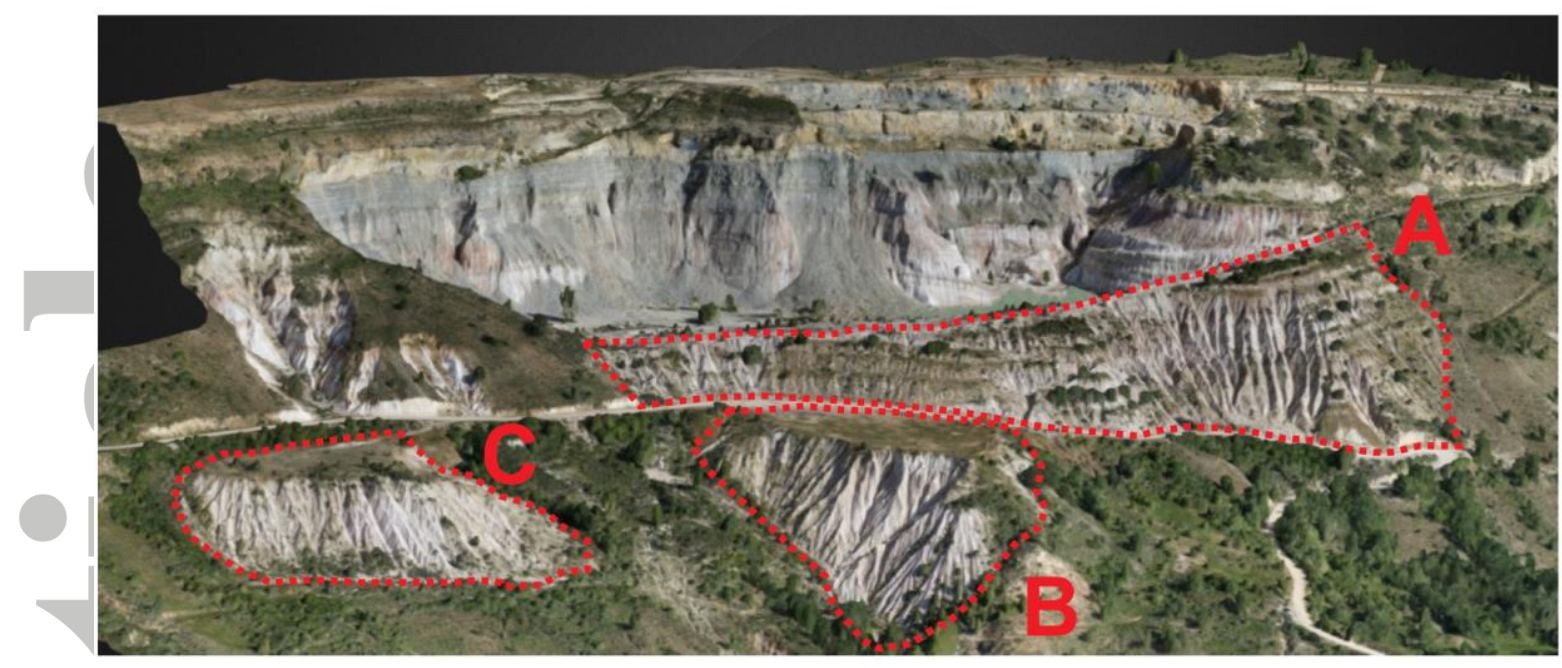

Figure 6 3D view of the current appearance (2016) of the Path to Poveda mined site. The dotted lines delineate the three studied waste dumps. (Image courtesy of the Consejería de Economía, Empresas y Empleo, Junta de Comunidades de Castilla-La Mancha).
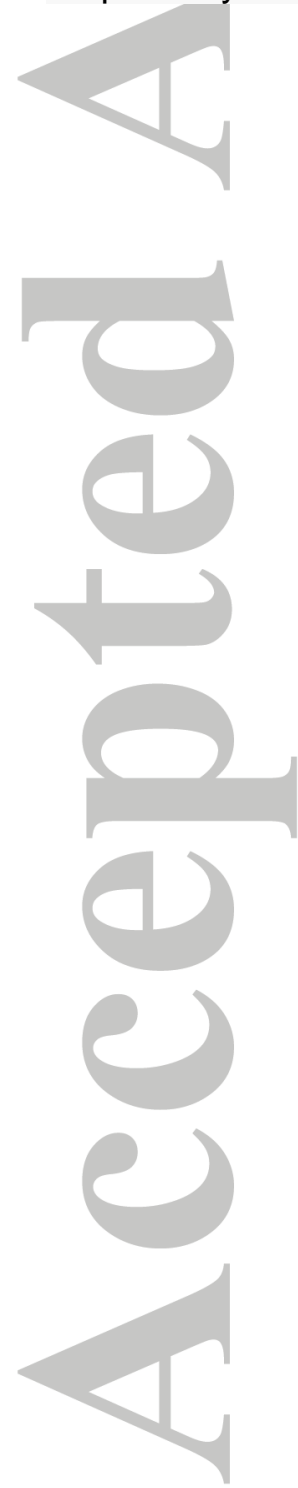

This article is protected by copyright. All rights reserved. 


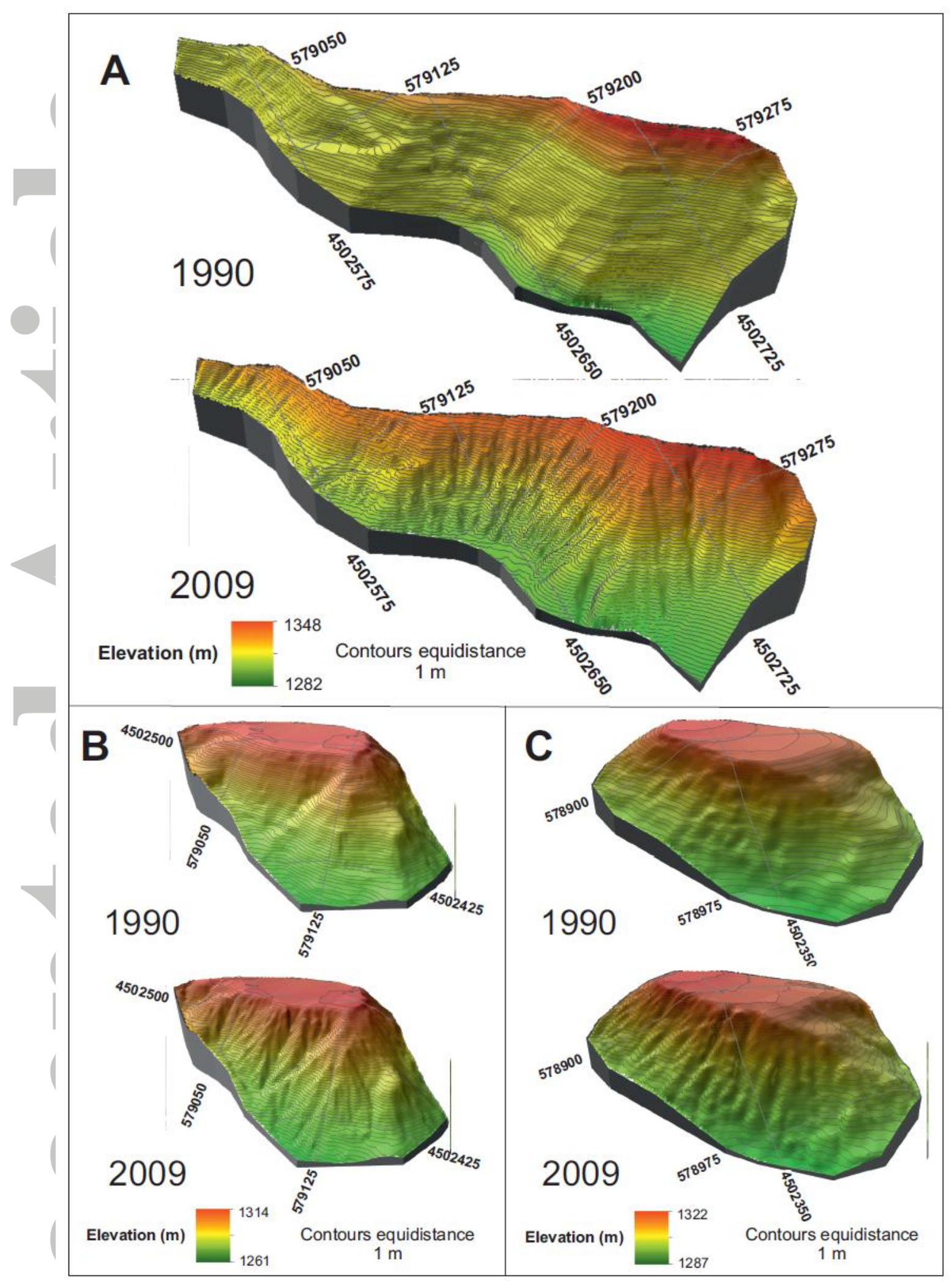

Figure 7 Digital Elevation Models (DEMs) of the Path to Poveda mined site waste dumps (named with the same letters (A, B, C) as in Figure 6). Top (1990), reconstructed DEM; bottom, situation in 2009, DEMs built from available LIDAR data, PNOA 2009. (Coordinate system UTM-30 N, Datum ETRS 1989). 


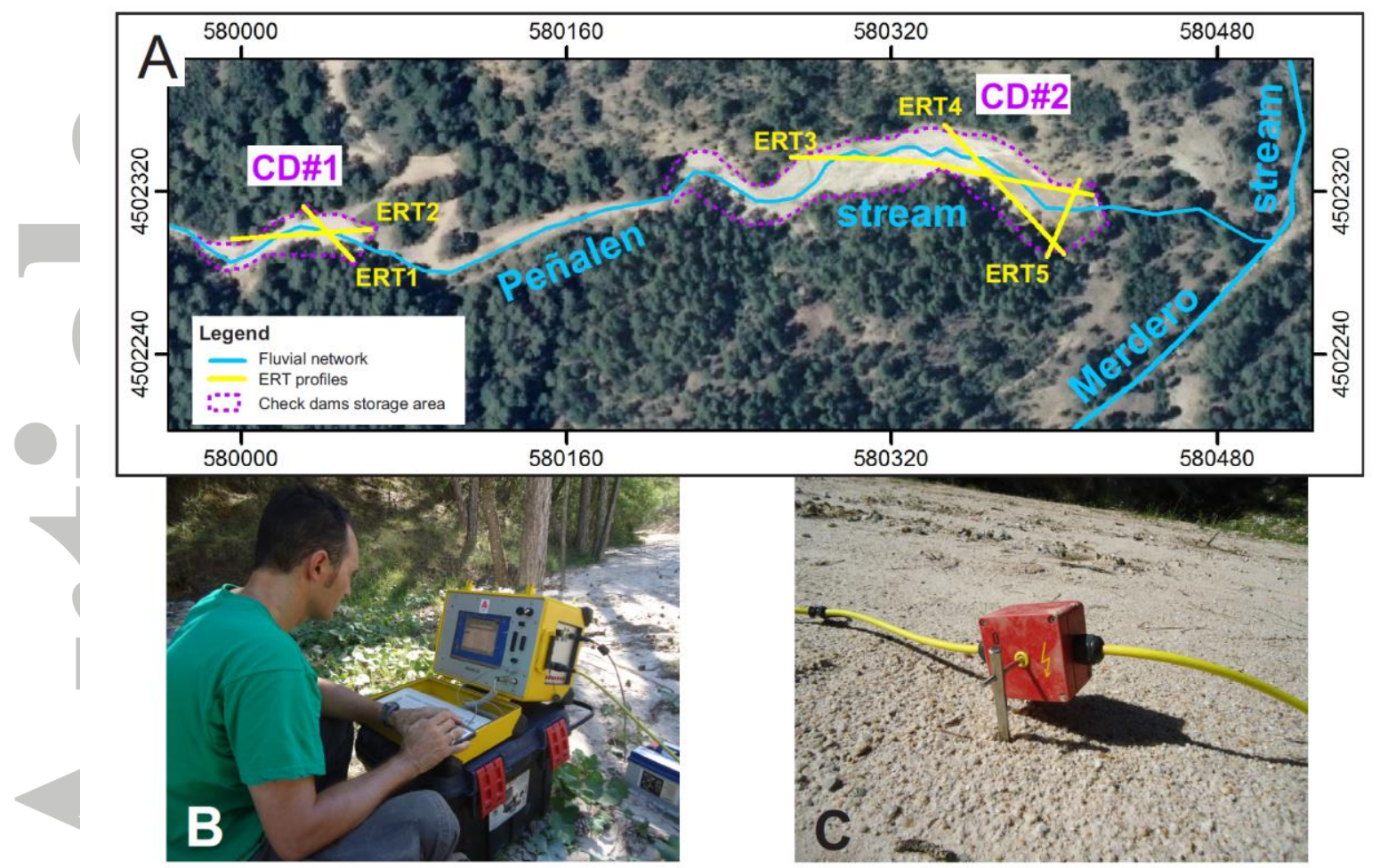

Figure $8 \mathrm{~A}$ ) Location of the Electrical Resistivity Tomography (ERT) profiles (Coordinate system UTM-30 N, Datum ETRS 1989); B) field measurements; C) detail of an electrode and multi-core cable.

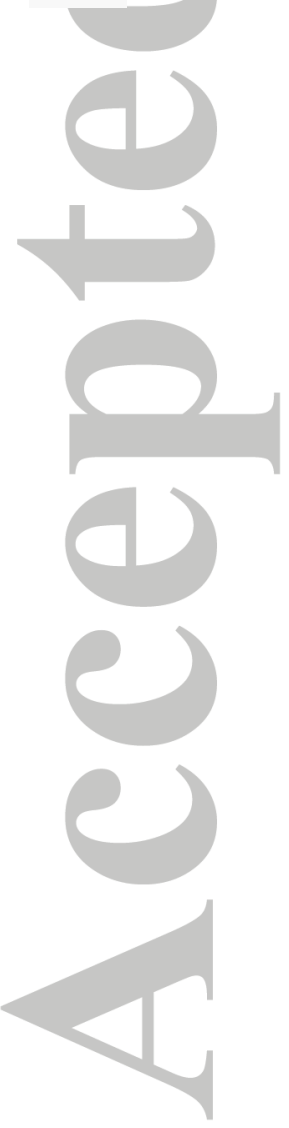

This article is protected by copyright. All rights reserved. 


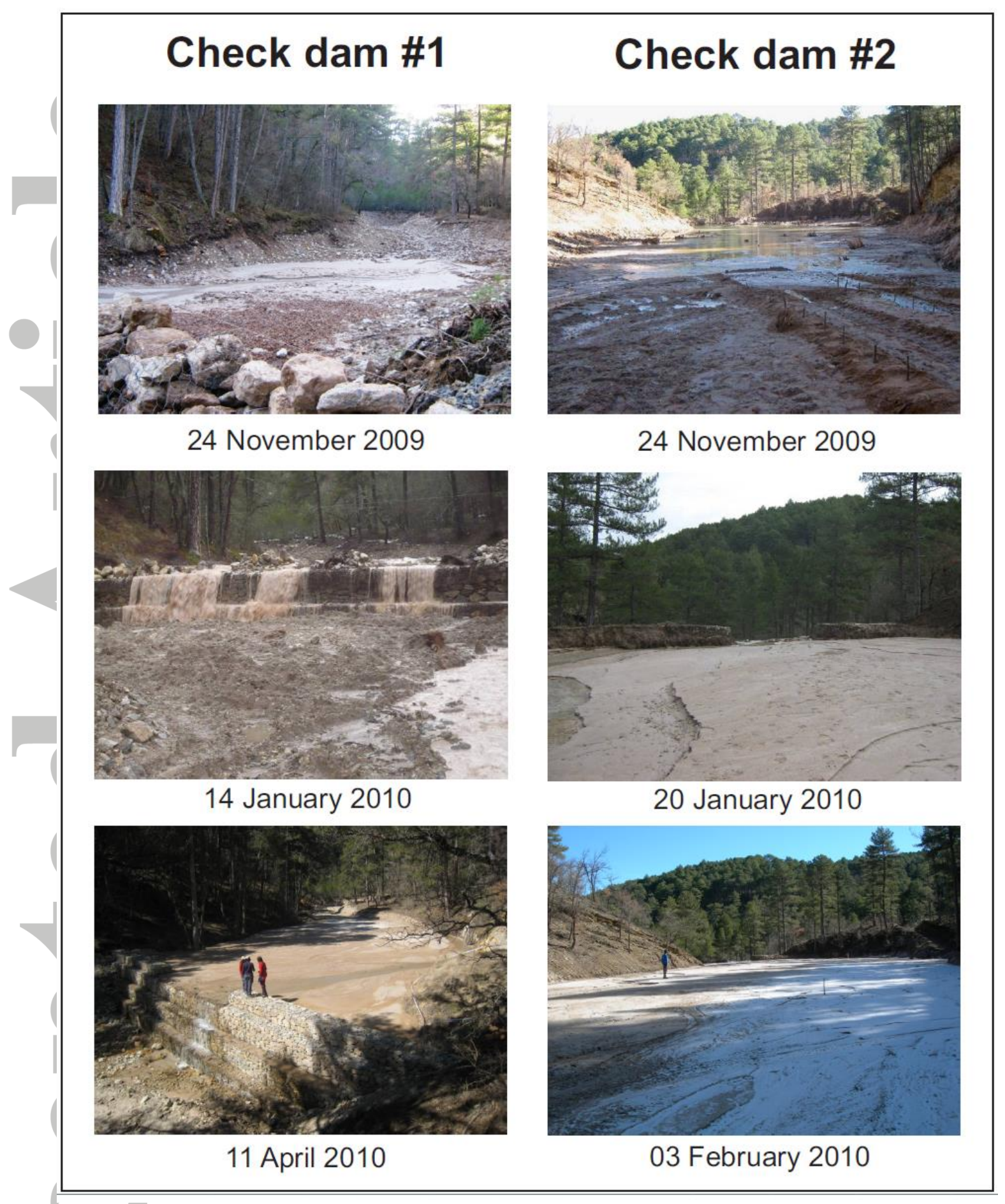

Figure 9 Check dam storage areas before and after the 10 December 2009 - 18 January 2010 period. Top: check dam \#1 under construction ( $3 \mathrm{~m}$ high) and check dam \#2 partially cleaned; middle: check dam storage areas completely filled by sediment; bottom: $4.5 \mathrm{~m}$ high check dam \#1 and check dam \#2 some months after the studied period, their storage areas were completely filled by sediment.

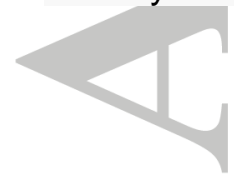

This article is protected by copyright. All rights reserved. 


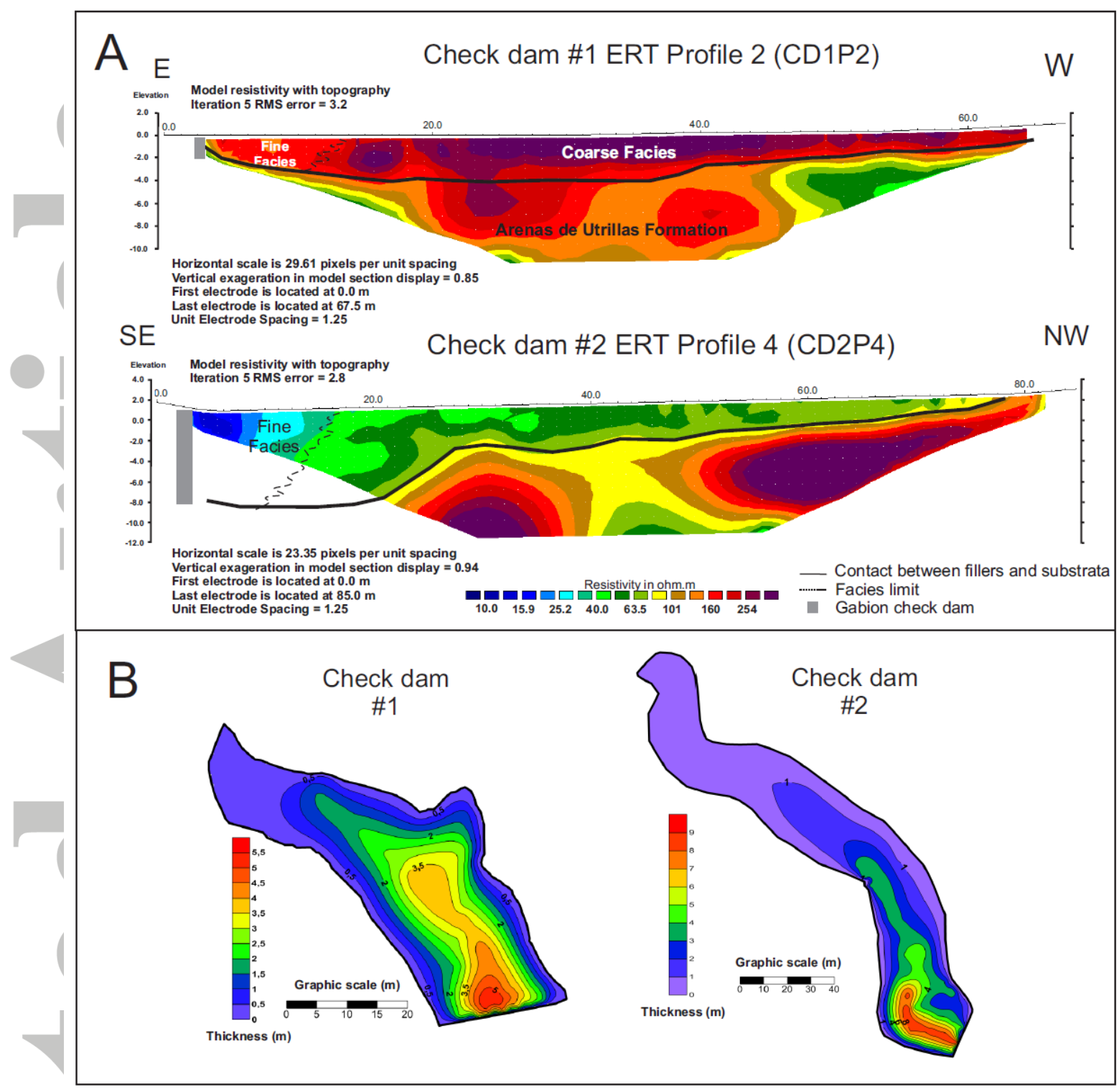

Figure 10 A) two examples of ERT profiles. Notice the contact between the sediment trapped by the check dams and the substrata. Also observe the fine facies settled upstream from the check dams; B) check dam storage area isopach maps. 

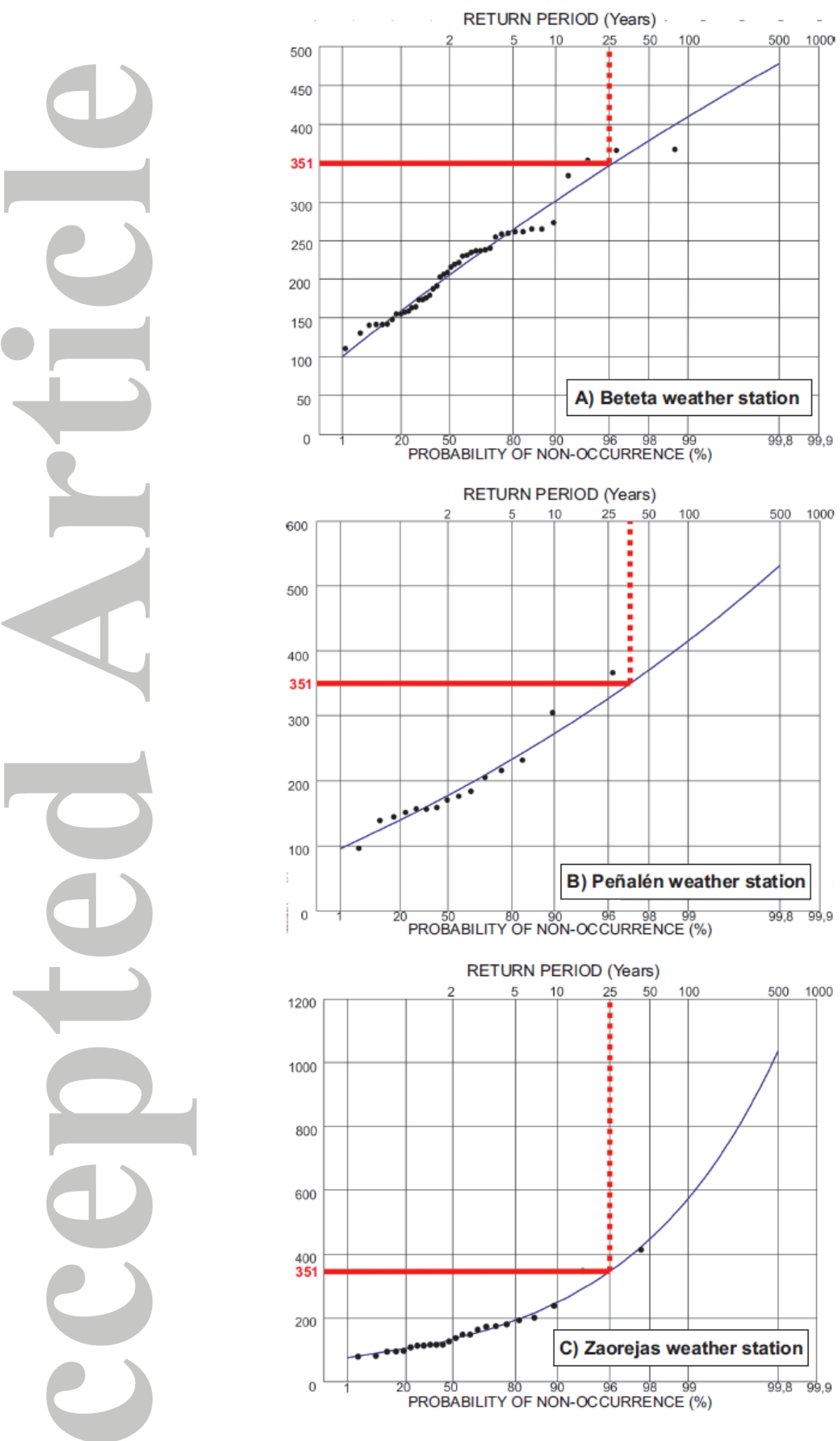

Figure 11 General Extreme Values (GEV) curves of A) Beteta, B) Peñalén and C) Zaorejas weather stations. Continuous lines represent the total rainfall volume $(351 \mathrm{~mm})$ for the period 10 December 2009 - 18 January 2010, and broken lines the estimated return period (years). 


\section{Waste dump erosional landform stability - a critical issue for mountain mining}

Cristina Martín-Moreno*, José F. Martín Duque, José M. Nicolau Ibarra, Alfonso Muñoz, and Ignacio Zapico

A mountain kaolin mine in East-Central Spain has been subject to severe erosion after its abandonment, in 1990, affecting the pristine ecosystems of a protected area (Alto Tajo Natural Park). This paper provides: (a) quantification of such erosion; (b) quantitative demonstration of the inefficiency of expensive check dams built as a correction measure; and (c) guidelines for a geomorphic-based ecological restoration of the area.
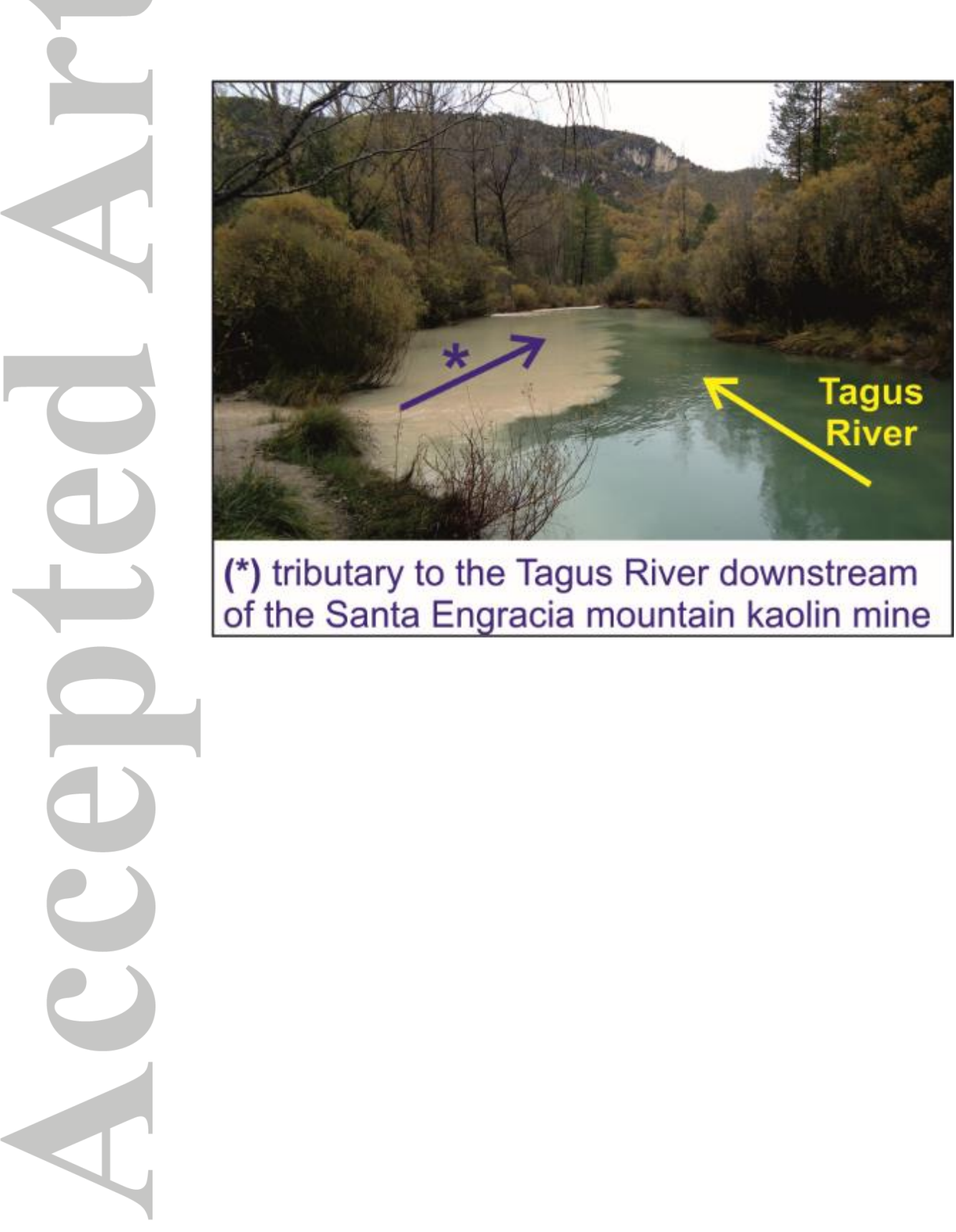

This article is protected by copyright. All rights reserved. 